\title{
The Avian Tectobulbar Tract: Development, Explant Culture, and Effects of Antibodies on the Pattern of Neurite Outgrowth
}

\author{
Stephan Kröger and Uli Schwarz \\ Max-Planck-Institut für Entwicklungsbiologie, D-7400 Tübingen, Federal Republic of Germany
}

The tectobulbar tract is the first long-distance projecting fiber pathway to appear during the development of the avian optic tectum (dorsal half of the mesencephalon). Immunologically stained wholemounts of the E3 mesencephalon reveal that the early tectobulbar axons course in a dorsalto-ventral direction and abruptly turn in a caudal direction shortly before reaching the ventral midline. During subsequent development, more tectobulbar axons are generated that form a parallel array of thick fascicles coursing ventrally within the mesencephalon. At this later stage of development, the tectobulbar tract bifurcates into an ipsilateral and contralateral pathway, both growing in a caudal direction near the mesencephalic ventral midline. Bifurcation and change in direction of growth is accompanied by a complete loss of the fasciculated growth pattern. Each tectobulbar axon is thus divided into a proximal fasciculated and a distal unfasciculated segment.

Tectobulbar fascicles occupy the most superficial surface layer of the mesencephalon at early stages and are displaced deeper into the tissue beginning at embryonic day 5 . In both of these locations, tectobulbar axons express molecules involved in axon-axon and axon-substrate interactions like the G4 antigen, neural cell adhesion molecule (N-CAM), neurofascin, and T61 antigen as revealed by immunohistochemistry and immunoblotting.

Stripes of the mesencephalon explanted onto a basal lamina substratum show vigorous outgrowth of neurites. These processes grow in fascicles at a growth rate of $40 \mu \mathrm{m} / \mathrm{h}$. Staining of the neurites with specific antibodies, as well as the position of the retrogradely labeled cell bodies, is in agreement with these processes being tectobulbar axons. This in vitro explant system was used to investigate the expression and possible functional involvement of N-CAM, neurofascin, G4 protein, and T61 antigen in the growth of these axons. The presence of antigen-binding fragments of polyclonal anti-G4 antibodies completely blocks fasciculation of the neurites but has no influence on their rate of elongation. Antibodies against N-CAM and neurofascin have

\footnotetext{
Received July 27, 1989; revised May 7, 1990; accepted May 10, 1990.

We wish to thank F. Rathjen, L. Niehörster, and S. Henke-Fahle for the kind gifts of various antibodies and purified proteins, as well as P. Godement for the introduction to the DiI-staining method. We are also grateful to $\mathrm{M}$. Nagel for her expert assistance, C. Seeland-Wöhrle and I. Baxivanelis for secretarial help, and R. Groemke-Lutz and R. Marshall for their skillful phctographic reproductions. This manuscript has been critically read and improved by E. Pollerberg, T. Allsopp, and H. O. Nornes. We appreciate the help of B. G. Wallace and U. J. McMahan during later states of the manuscript's preparation.

Correspondence should be addressed to Dr. Stephan Kröger, Department of Neurobiology, Stanford University, Stanford, CA 94305-5401.

Copyright (c) 1990 Society for Neuroscience $0270-6474 / 90 / 093118-17 \$ 03.00 / 0$
}

no detectable effects. The number and length of the in vitro growing axons are reduced by the monoclonal T61 antibody. This effect is reversible. The elucidation of the exact course in vivo and the accessibility to the axons growing in vitro make the tectobulbar tract an excellent model system for the investigation of the role of these and other proteins in axonal growth and guidance during the development of the CNS.

The characteristic pattern of nerve tracts that connect distant parts of the CNS is generated during embryonic development by axonal elongation along stereotyped pathways. The precision and reproducibility of axonal growth results from the exact guidance of the processes' leading tip (growth cone) to the appropriate target cell. Adhesive as well as repellent cell-surface interactions between the highly motile growth cone and its immediate cellular and extracellular environment are considered to play a crucial role in the establishment of neuronal trajectories during development (Bray and Hollenbeck, 1988). A number of glycoproteins have been characterized and implicated in the control of axonal extension and fasciculation during CNS development (Hoffman et al., 1982; Henke-Fahle and Bonhoeffer, 1983; Keilhauer et al., 1985; Kruse et al., 1985; Stallcup and Beasley, 1985; Fischer et al., 1986; Chang et al., 1987; Lagenaur and Lemmon, 1987; Rathjen et al., 1987a, b; Tomaselli et al., 1988). Probably, a combination of several types of interactions, precisely tuned and mediated by different molecules, results in the generation of axonal trajectories during embryonic development (Jessell, 1988).

The avian embryonic mesencephalon has previously been the subject of many developmental studies, because it is easily accessible in ovo for transplantation (Alvarado-Mallart and Sotelo, 1984; Senut and Alvarado-Mallart, 1987; Thanos and Dütting, 1987) and has a uniquely laminated structure (LaVail and Cowan, 1971a; Gray et al., 1988). In addition, the mesencephalon (whose dorsal half is called the optic tectum) receives a massive, topologically organized neuronal projection from the contralateral retina and has therefore been the tissue of choice for the investigation of neural specificity (DeLong and Coulombre, 1965; Rager, 1980; Thanos and Bonhoeffer, 1983; Walter et al. 1987a,b). The mescncephalon devclops from the middlc of the primary brain vesicles of the cranial neural tube in a well characterized rostroventrolateral to caudodorsomedial gradient (LaVail and Cowan, 1971a). Until embryonic day 2 (E2), the paired, thin-walled mesencephalon consists only of neuroepithelial cells. These rapidly dividing precursor cells are radially oriented between the pia and the ventricular surface and form a pseudostratified neural epithelium with their cell bodies located at various levels between the ventricle and the external 
limiting membrane (Sauer, 1935). Between E2 and E3, the first neuroepithelial cells cease their cell division cycle and differentiate into neuroblasts (Windle and Austin, 1935; Lyser, 1966; LaVail and Cowan, 1971 b; Puelles and Bendala, 1978; Puelles et al., 1987; Layer et al., 1988). These cells send out axons that grow circumferentially towards the ventral region of the mesencephalon. The axonal processes group together in fascicles and eventually form the tectobulbar tract (Goldberg, 1974). These tectofugal neurons have also been named circumferential fibers (Puelles and Bendala, 1978), tangential fibers (Windle and Austin, 1935), or tectal ganglion cells (Domesick and Morest, 1977).

During the carly stages of development, the tectobulbar processes form the most superficial layer of the mesencephalon (marginal zone), but with proceeding development, these axon bundles are displaced deeper into the tissue and eventually contribute to the stratum album centrale (SAC), the main tectal efferent layer (Goldberg, 1974; Puelles and Bendala, 1978). The surface of the mesencephalon is then formed by the stratum opticum ( $\mathrm{SO}$ ), a lamina that contains retinal axons, originating in the contralateral eye (Rager and von Oeynhausen, 1979).

Although a considerable amount of information about the gross morphological and anatomical development of the mesencephalon has accumulated, its investigation has not yet advanced from the general descriptive level to the cellular, molecular, and functional level. In the present study, we characterize the tectobulbar tract in the avian embryonic mesencephalon using newly developed, high-resolution staining methods and antibodies directed against several defined cell-surface molecules. In addition, we established an explant system that permits vigorous and selective outgrowth of tectal axons in vitro, thus allowing a detailed study of how antibodies directed against neuronal cell-surface molecules perturb axonal growth. These perturbation studies show that this explant system is excellently suited for the investigation of molecules involved in axonal elongation and neurite fasciculation during the development of a defined CNS pathway.

\section{Materials and Methods}

Antibodies. Polyclonal rabbit $\mathrm{F}(\mathrm{ab})_{2}$ fragments against the $\mathrm{G} 4$ protein (Rathjen et al., 1987a; $5 \mathrm{mg} / \mathrm{ml}$; dilution, 1:1000 for blots, 1:2000 for immunofluorescence), F6 (neurofascin; Rathjen et al., $1987 \mathrm{~b} ; 5 \mathrm{mg} / \mathrm{ml}$; $1: 1000$ in blots, $1: 500$ in immunofluorescence), and neural cell adhesion molecule (N-CAM) (Hoffman et al., 1982; $4.8 \mathrm{mg} / \mathrm{ml}$; dilution, 1:1000 in blots, 1:800 in immunofluorescence) were a generous gift of Dr. F. Rathjen (Hamburg, FRG). The chicken G4 antigen has been shown to be homologous to mouse Ll (Rathjen and Schachner, 1984), rat NILE (Stallcup and Beasley, 1985), Ng-CAM (Grumet and Edelmann, 1984), and chick 8D9 antigen (Lemmon and McLoon, 1986). The monoclonal antibodies T61 (Henke-Fahle and Bonhoeffer, 1983; partially purified IgG fraction from mouse ascites; dilution: $1: 3000$ in blots, $1: 1000$ in immunofluorescence), and Q211 (Rösner et al., 1988; mouse ascites; dilution, 1:100) were obtained from Dr. S. Henke-Fahle (Tübingen, FRG). The monoclonal antibody Julia-1 (L. Niehörster, S. Kröger, and U. Schwarz, unpublished observations; see also Schwarz et al., 1987; ascites fluid; dilution, 1:1000) was kindly provided by L. Niehörster (Tübingen, FRG).

Wholemounts of the avian embryonic mesencephalon. Both halves of the embryonic mesencephalon were dissected out of the embryo in $\mathrm{Ca}^{2+}$ and $\mathbf{M g}^{2+}$-free PBS and cut midsagittally. One half was Hat-mounted, pial side upward, on a black nitrocellulose filter (SM 13006; Sartorius, Göttingen FRG) for support as previously described for embryonic retinae (Halfter and Deiss, 1984). The meninges were carefully removed with watchmaker's forceps, and the resulting mesencephalon wholemount was fixed for $1 \mathrm{hr}$ in $4 \%$ paraformaldehyde in $0.1 \mathrm{M}$ potassium phosphate buffer $(\mathrm{pH}, 7.1)$. The wholemounts were washed extensively in $0.2 \%$ BSA in PBS, incubated with rabbit anti-G4 F(ab), fragments $(2.5 \mu \mathrm{g} / \mathrm{ml})$, washed again thoroughly in PBS/BSA, and stained with the secondary antibody, fluorescein isothiocyanate (FITC)-coupled goat antirabbit (1:1000; Dianova, Hamburg, FRG). After a final wash in PBS/ BSA, the specimens were mounted in PBS-glycerol $(1: 1, v / v)$ and examined under a Zeiss standard epifluorescence microscope. Photographs were taken on Ilford HP5 film, and wholemounts were reconstructed from serial pictures. Incubation of wholemounts with the secondary antibody only gave controls with negligible staining.

Wholemounts of the complete caudal half of the brain were prepared, in principle, as described above. The whole brain was dissected out of the embryo and freed of the meninges. The prosencephalon and diencephalon were discarded. The remaining caudal part, including the mesencephalon, metencephalon, myelencephalon, and the rostral part of the spinal cord, were cut sagittally in the dorsal midline as described by Aitken (1987). Both hemispheres, still connected with each other on the ventral side, were attached to a piece of nitrocellulose as mechanical support, with the ventricular side facing the filter.

Dil staining. Fixed tissue was stained with D282; 1, 1', diostadecyl3,3,3',3'-tetramethylindocarbocyanine perchlorate (DiI) (Molecular Probes Inc., Eugene, OR) as described by Godement et al. (1987). Briefly, a small crystal of dye was placed cither on the surface of embryonic brain wholemounts, or on the distal parts of tectobular axons, that had been cultured in vitro for I day. Following dye placement, both tissues were stored for 2 months in the dark. Staining was observed directly in wholemounts or after cryostat sectioning of the explant stripe.

Histology. For immunohistochemistry, whole heads of E5 and E8 chick embryos were fixed and coronally cryostat-sectioned as described by Halfter (1987). Parallel, $15-\mu \mathrm{m}$-thick sections were mounted on slides, coated with $0.5 \%$ gelatin and $0.05 \%$ chromalumn, and stained with antibodies as described by Halfter et al. (1987). Equivalent parts of the most advanced rostroventral region of the mesencephalon were selected in the parallel sections and photographed. The nomenclature of the 6 major laminae of the mesencephalon was adopted from LaVail and Cowan (1971a).

Gel electrophoresis and antigen detection on blots. SDS-PAGE was performed essentially as described by Neukirchen et al. (1982) and von Boxberg (1988). Ultrathin gels that were covalently bound to glass plates consisted of a 5 or $7.5 \%$ acrylamide resolving gel and a $4 \%$ stacking gel. Tecta and retinae were dissected free of the meninges and pigment epithelium, respectively, and homogenized in $10 \mathrm{mM}$ Tris- $\mathrm{Cl}(\mathrm{pH}, 7.4)$ with $1 \mathrm{mM}$ zinc chloride and $1 \mathrm{mM}$ spermidine. After centrifugation at $30,000 \times g$, the resulting pellet (e.g., a crude membrane preparation) was transferred into solubilizing buffer ( $10 \%$ SDS, $5 \%$ mercaptoethanol). One-microliter samples containing $0.5 \mu \mathrm{g}$ protein were applied to each lane of the gel. Isolated G4 protein, neurofascin, and N-CAM were directly dissolved in solubilizing buffer at a concentration of $30 \mu \mathrm{g} / \mathrm{ml}$. The proteins had been affinity-purified from adult chick brains and were a generous gift of $F$. Rathien. After electrophoresis, proteins were transferred onto nitrocellulose, which was subsequently blocked in $2 \%$ polyvinylpyrrolidone (PVP) (Sigma, Munich, FRG) for $2 \mathrm{hr}$ and incubated with the primary antibody diluted in PBS containing $0.05 \%$ Tween 80 and $0.1 \%$ PVP. The nitrocellulose was then washed 3 times in the same buffer and incubated with the secondary antibody (peroxidase AffiPure goat anti-rabbit $F\left(\mathrm{ab}^{\prime}\right)_{2}$ fragments; dilution, 1:1000; Dianova, Hamburg, FRG). Staining was performed with 4-chloro-1-naphthol $(0.5 \mathrm{mg} / \mathrm{ml})$ and $\mathrm{H}_{2} \mathrm{O}_{2}(0.015 \%)$. Some samples were incubated only with the secondary antibody to check for nonspecific binding. No staining was visible in these controls.

Explants. Mesencephalic explants could be obtained from E3-E6 chick embryos. Maximal axon outgrowth was observed when the donor age was E5. Explantation of stripes from E7 or older tecta did not result in axonal outgrowth, but multipolar neuronal cells left the tissue (S. Kröger, unpublished observation). For explantation, optic tecta were dissected out of the embryo, split midsagittally, and spread on a filter, with the former ventricular side facing the nitrocellulose, as previously described for retinal explants (Halfter et al., 1983). For optimal outgrowth, a perfectly flat-mounted mesencephalon was a necessary prerequisite. Folds or lesions result in non-neuronal cells leaving the explant. Orientation is possible as the ventral tissue bulge (tegmentum) is clearly visible. After removal of the meninges, the mesencephalon was cut into 250 $\mu \mathrm{m}$-wide stripes in an anterior-to-posterior direction. The stripes were placed with the former pial side facing the substrate on a moist basal lamina, prepared from E8 embryonic chick retinae according to Halfter et al. (1987). No difference in the pattern of axonal growth was observed between basal laminae with the endfeet of neuroepithelial cells attached and basal laminae freed of the endfeet by detergent extraction (Halfter 
et al., 1987). Stripes were usually taken from the central third of the mesencephalon to avoid explantation of axons from the mesencephalic nucleus of the trigeminal nerve (Rogers and Cowan, 1973). After a 30minute attachment period in a $37^{\circ} \mathrm{C}$ humidified incubator with $4 \% \mathrm{CO}_{2}$, culture medium was carefully added. The medium consisted of Dulbecco's modified Eagle's medium (DMEM) (Gibco, Eggenstein, FRG) supplemented with $10 \%$ fetal calf serum and $2 \%$ chicken serum. In some cases, cytosine arabinoside (Ara $\mathrm{C}$ ) was included in the culture medium at a concentration of $10^{-5} \mathrm{M}$ to block cell proliferation. Cultures were usually grown for $40 \mathrm{hr}$ and fixed thereafter in $4 \%$ paraformaldehyde. For better documentation, the axons were stained with the Q211 antibody as described for cryostat sections. This antibody binds to the ganglioside $\mathrm{GD}_{3}$ (Rösner et al., 1988) and intensely labels all postmitotic neurons in the CNS. The same procedure was used for staining processes in vitro with anti-G4, anti-neurofascin, and anti-N-CAM rabbit polyclonal antisera, as well as the T61 monoclonal antibody. Specimens stained only with the secondary antibody showed only negligible background labeling.

The growth rate of axons was estimated by measuring their length at given time intervals with a calibrated ocular micrometer. The growth rate was calculated as the mean of at least 3 different experiments with 4 explants each. The influence of anti-F6, anti-N-CAM, and anti-G4 antibodies on tectobulbar axons growing in vitro was investigated by adding $F(a b)_{2}$ fragments (final concentrations, $0.1-1 \mathrm{mg} / \mathrm{ml}$ ) to the culture medium at the time of explantation. The monoclonal T61 antibody was used at a final concentration of approximately $80 \mu \mathrm{g} / \mathrm{ml}$. Quantification of the growth inhibitory effect of the T61 antibody was performed by comparing the length of the axon front of explant stripes that were previously located next to each other in the tectum. The reduction of the number of axons by the T61 antibody was quantified by counting the number of fascicles leaving a segment of $1000 \mu \mathrm{m}$ of the explant stripe in the presence and absence of the antibody.

\section{Results}

\section{The course of the tectobulbar axons}

Wholemounts stained with appropriate antibodies are well suited to visualization of the different fiber tracts in the early embryonic mesencephalon. The G4 antibody was chosen because it brightly labels all long-distance projecting axonal pathways but leaves cell bodies unstained, thus reducing the anatomical complexity of the picture obtained. Due to massive cell proliferation and the resulting increase in thickness, wholemounts of optic tecta from embryos older than E8 are difficult to flatmount, do not allow complete penetration of the antibodies, and were therefore not investigated.

Figure 1 shows a flat-mounted E3 mesencephalon that was stained with anti-G4 antibodies to reveal all long-distance projecting axon trajectories. The tectobulbar processes course in a dorsal-to-ventral direction within the mesencephalon (Fig. 1, small arrows) but on approaching the ventral midline, they abruptly turn in a posterior direction towards the spinal cord. After this $90^{\circ}$ turn, they descend parallel to the medial longitudinal fasciculus (MLF), which originates outside the figure at the caudal end of the diencephalon (Rhines and Windle, 1941; Lyser, 1966; Letourneau et al., 1988). Few tectobulbar processes are present at this time, and they simultaneously appear across the entire dorsal third of the mesencephalon. No difference in the number of processes between the anterior and posterior parts of the mesencephalon was detected; a difference might have been expected from the well-known anterior-to-posterior gradient of cell differentiation.

With proceeding development, more tectobulbar axons are generated that join the already existing fibers (not shown). By E6, the tectobulbar axons have formed a parallel array of thick fascicles still coursing in a dorsal-to-ventral direction (Fig. 2A). The diameter of each fascicle is approximately $20 \mu \mathrm{m}$. Frequently, axons shift as small bundles from one fascicle to a neighboring one (Fig. $2 C$ ). At the ventroanterior pole, tectobulbar axons are displaced from the lateral surface, and retinal axons begin to invade the most superficial layer of the mesencephalon. They grow as unfasciculated single axons on top of and at a right angle to the tectobulbar fascicles (Fig. $2 B$ ). Their identity as retinal axons was confirmed by their anterograde labeling after intraocular injection of rhodamine $\beta$-isothiocyanate (RITC) according to Thanos and Bonhoeffer (1983) and by their absence in embryos where the contralateral eye anlage had been extirpated (data not shown). Although retinal and tectobulbar axons are located in close proximity, they do not have direct contact with each other but are spatially separated by cells that are immunologically negative for G4 protein (data not shown).

Several other fiber tracts can be observed in E6 wholemounts: the anterior commissure connecting both tectal halves (Figs. 1, $2 A$, large arrows) and the mesencephalic trigeminal tract (Fig. $2 A$, curved arrows) that projects from the dorsal midline of the caudal tectal third, at a slight angle to the tectobulbar fascicles, and out of the mesencephalon to the trigeminal nerve (Fig. 2D; Rogers and Cowan, 1973).

Bctwecn E3 and E6, massive ccll proliferation takcs placc in the optic tectum, and therefore the surface area of the mesencephalon increases from $4 \mathrm{~mm}^{2}$ to $25 \mathrm{~mm}^{2}$. Correspondingly, the amount of axons visible in wholemounts increases in number. The exact course of the tectobulbar axons outside the optic tectum cannot be revealed with G4 staining because, on E6, the ventral region of the mesencephalon (tegmentum) is occupied by several other axonal tracts that also express the G4 protein. In order to investigate the orientation of the tectobulbar axons near the ventral midline and to obtain information about the morphology of their cell bodies, wholemounts of the caudal part of E6 brains were prepared. A small crystal of DiI was placed on the surface of the fixed mesencephalon in such a position as to label tectobulbar axons anterogradely and their somata retrogradely. Figure $3 a$ shows a schematic representation of the experiment.

The majority of cell bodies retrogradely stained by DiI are round or oval-shaped with a diameter of $10 \mu \mathrm{m}$. Each cell body has a process that heads towards the pia first, then bends just beneath the meningeal surface (Fig. 3c, arrows) and continues to grow in a medial direction parallel to the pial surface. Only 1 process is extended from every cell body (Fig. 3, $b, c$ ). Most processes seem to be properly oriented from the beginning because a correction of growth direction near the cell body was not observed. Figure $3, d-f$, shows a few rare exceptions where the cell bodies have already developed highly branched appendages, presumably dendritic processes. These complex cells are most frequently found in the anterior mesencephalon, the part that is developmentally most advanced. In contrast to the "simple" cells, their cell bodies are located on top of (more meningeal to) the axonal processes.

Anterograde labeling reveals tectobulbar axons coursing in thick fascicles in a dorsal-to-ventral direction within the optic tectum, resembling the picture obtained in G4-stained wholemounts. On approaching the ventral midline, however, they completely alter their bundled structure, defasciculate, and split into 2 different subpopulations (Fig. $3 g$ ). One of these turns caudally on the ipsilateral side (Fig. $3 a$, pathway 1), whereas the other crosses the midline before abruptly changing its direction of growth on the contralateral side (pathway 2). To determine if individual axons send branches down both sides of 


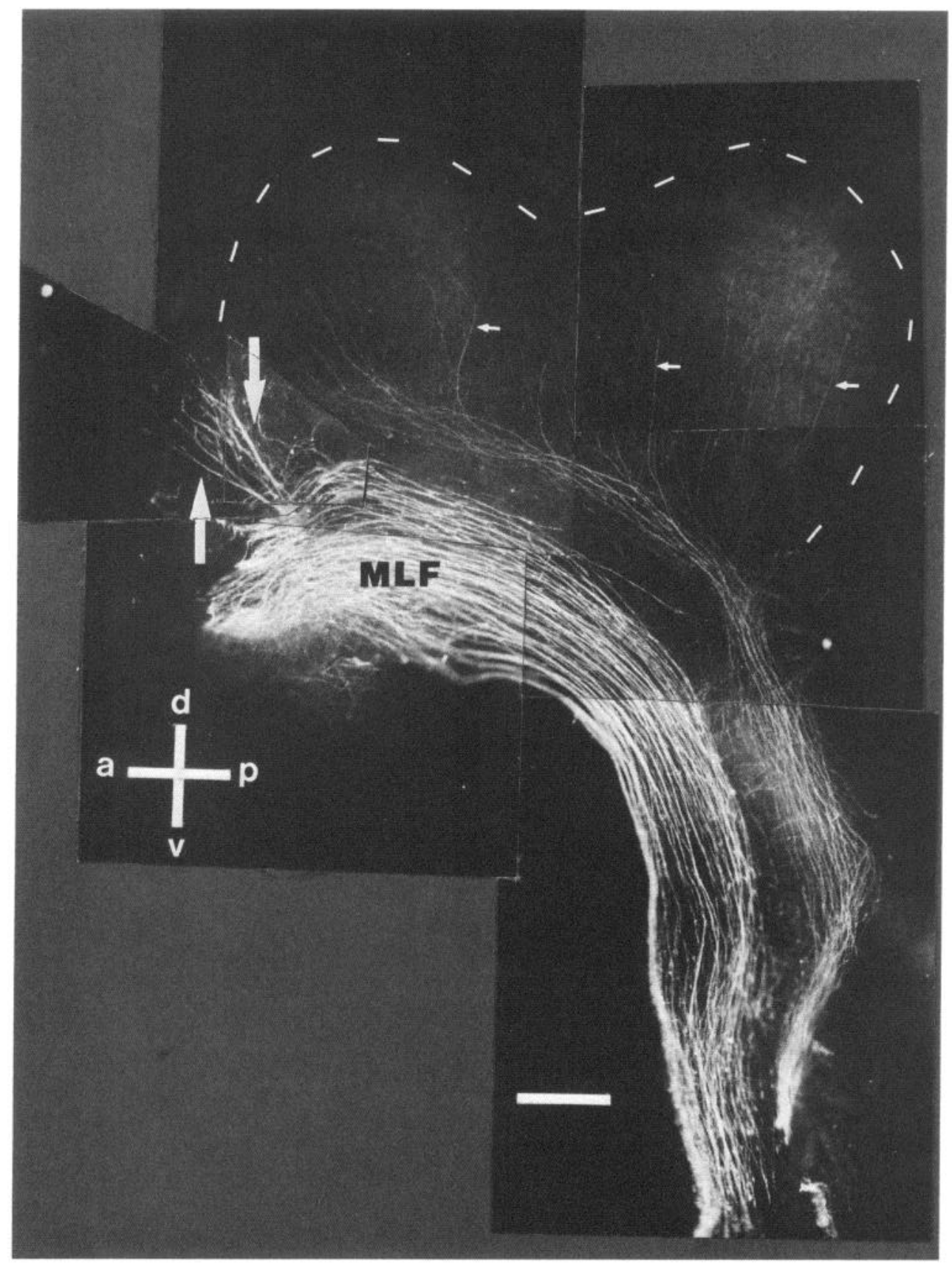

Figure 1. Left hemisphere of E3 mesencephalon wholemount stained with anti-G4 antibody. Both hemispheres were dissected out of the embryo and cut midsagittally. One half was flatmounted on nitrocellulose and stained with the G4 antibody to label all longdistance axonal projections. Tectobulbar axons (small arrows) course in a dorsal-to-ventral direction until they reach the bottom of the mesencephalon (tegmentum), where they make a $90^{\circ}$ turn and grow in a posterior direction, parallel to the medial longitudinal fasciculus $(M L F)$, towards the spinal cord. The origin of the medial longitudinal fasciculus is located to the anterior, outside the figure at the caudal end of the diencephalon. Large arrows show the anterior commissure connecting both tectal halves. The broken line delineates the mesencephalon outline. $d$, dorsal; $v$, ventral; $a$, anterior; $p$, posterior. Scale bar, $200 \mu \mathrm{m}$. the spinal cord or if separate populations of cells projected ipsilaterally and contralaterally, very small DiI crystals, which allow selective labeling of only a few processes, were applied. Careful investigation of these specimens showed that the contralateral axons are not collaterals branching off the ipsilateral processes, but instead are separate axons originating from cell bodies distributed evenly over the whole tectal hemisphere. The ipsilateral projection of one tectal half does not combine with the contralateral pathway of the opposite tectal half to form 1 axonal trajectory. Instead, both pathways stay separate from each other with the contralateral pathway coursing nearer to the ventral midline (not shown). Only 1 or 2 axons per preparation were observed to cross the midline and invade the contralateral optic tectum in a ventral to dorsal direction (Fig. 3a, pathway 3). Ascending processes to higher brain centers are not labeled.
The ipsilateral and contralateral projections contain about the same number of axons and have advanced approximately the same distance. No growth cones can be traced in the E6 brain wholemount beyond the caudal border of the metencephalon.

\section{Biochemical characterization of the tectobulbar axons in vivo}

Antibodies directed against several cell-surface proteins were used to detect the spatial and temporal distribution of the corresponding antigens by immunoblotting and immunohistochemistry. E5 and E8 tecta were chosen because they represent 2 different but defined stages during the development of the tectobulbar tract. Until E5, tectobulbar axons grow in fascicles within the most superficial layer, called the marginal zone, but beginning on E5.5, they shift to deeper layers as they are displaced from the tectal surface by cells migrating laterally from 


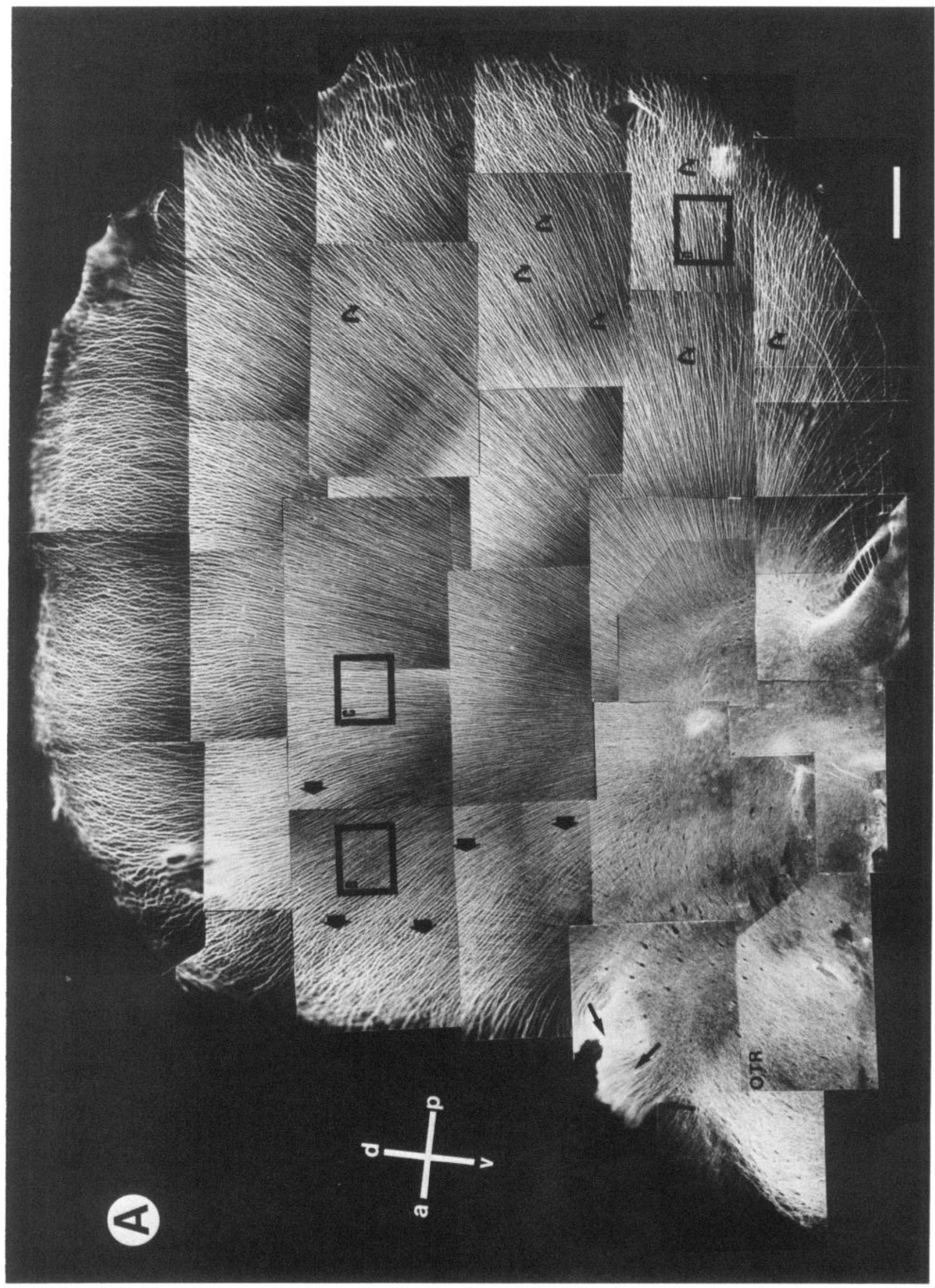




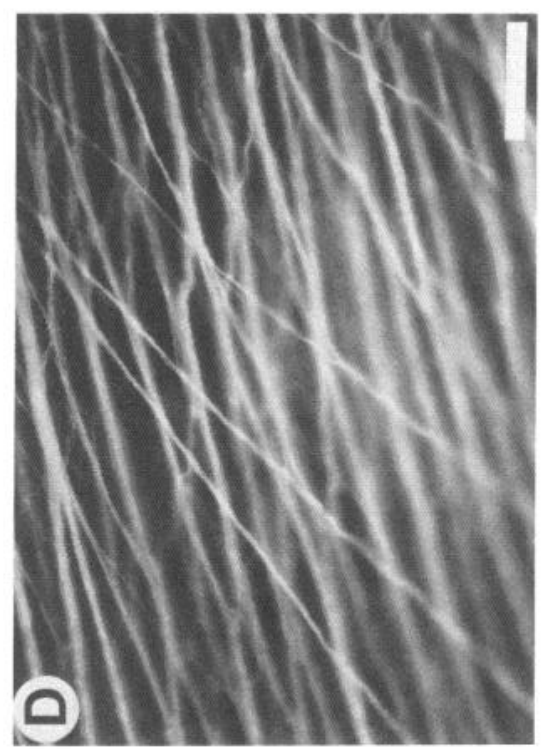

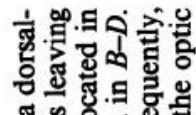

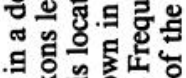

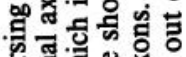

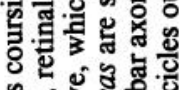

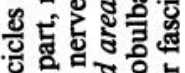

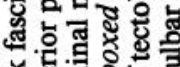

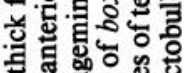

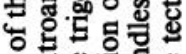

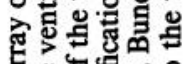
于

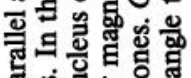

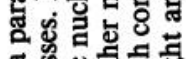
席.

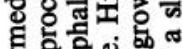
응 융혀 额. 记最 包运

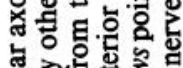

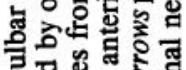

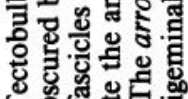

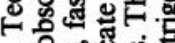
نे

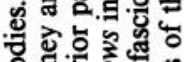

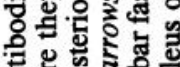
范言 प 305

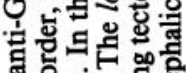

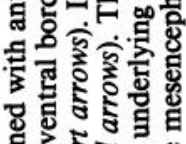

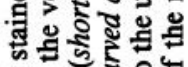
范密

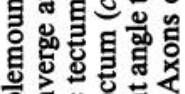

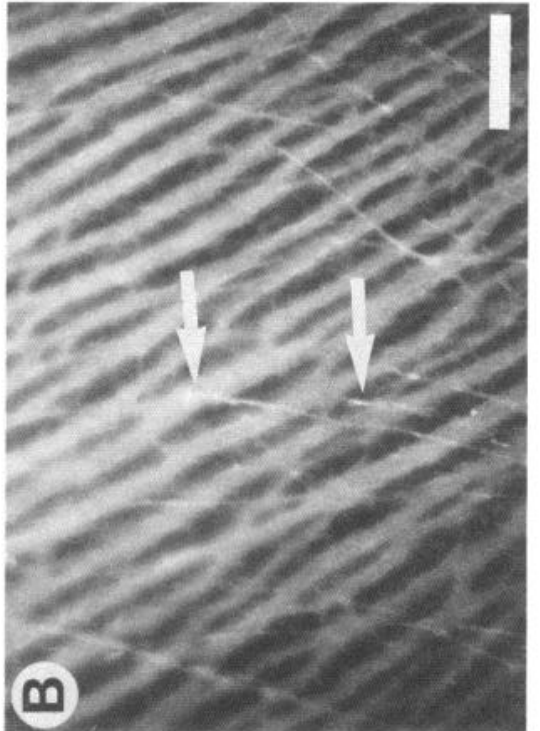

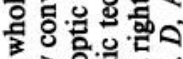

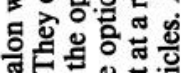
可

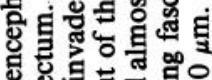

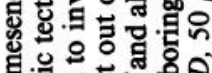

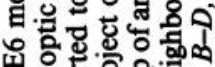
녕연. 势

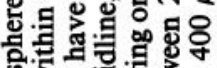

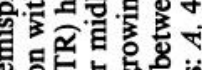
동응응 㫐苟总

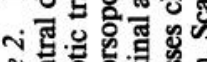
突

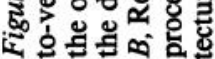



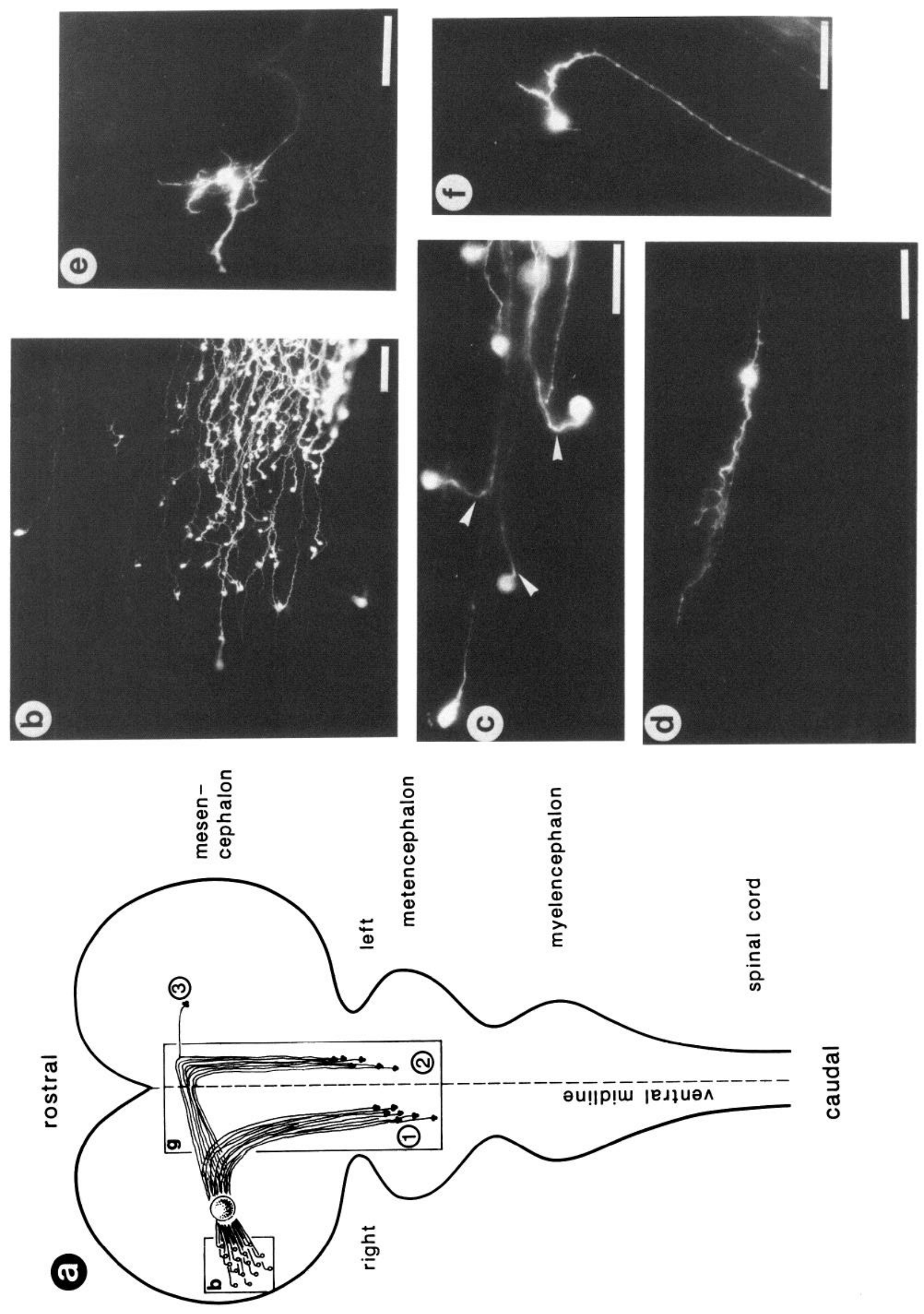


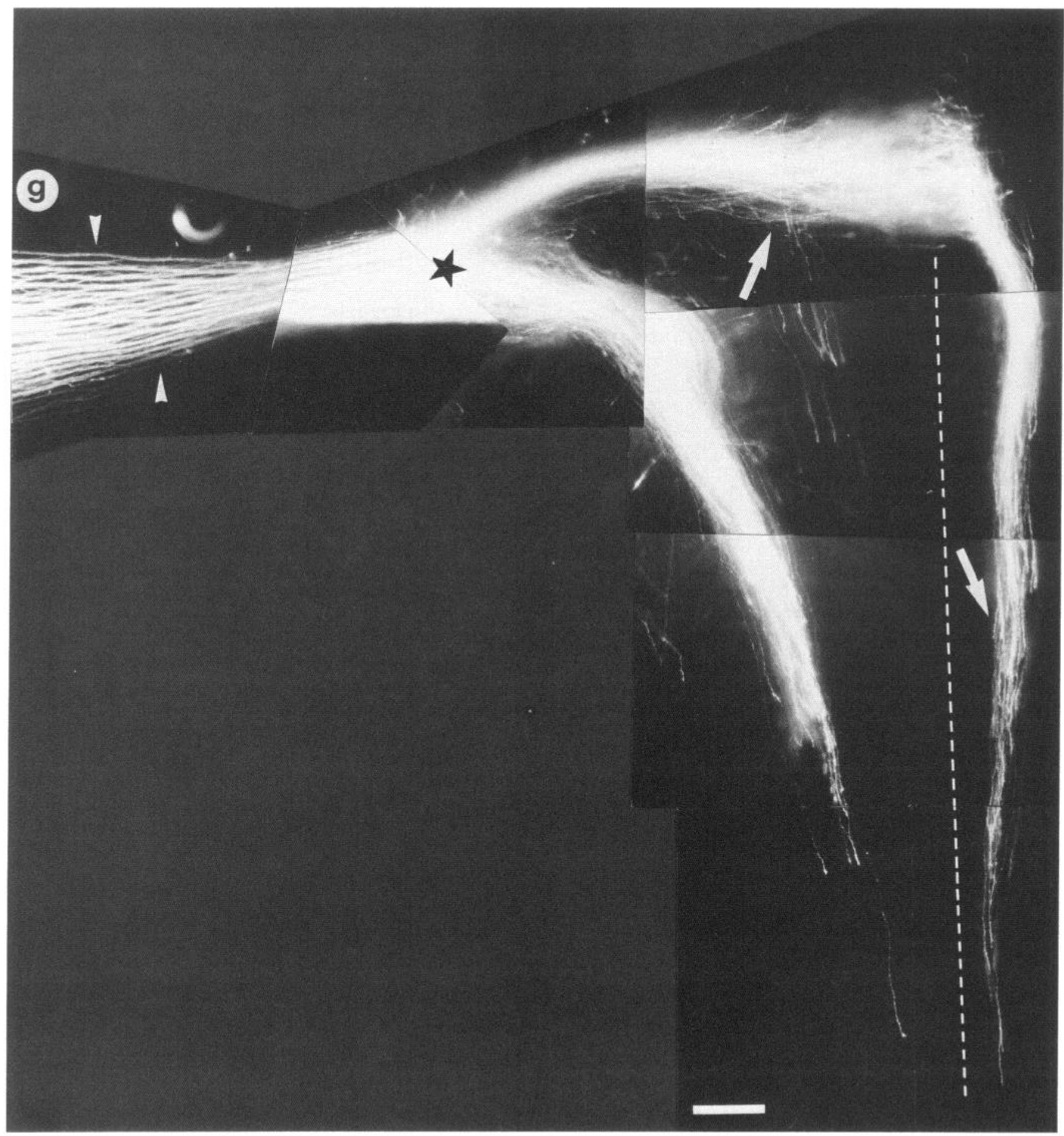

Figure 3. Retrograde and anterograde staining with DiI of tectobulbar axons in fixed wholemounts of complete caudal E6 brains. $a$, Schematic representation of the experiment. Cell bodies, as well as their processes, were stained by placing a crystal of DiI on the surface of the central mesencephalon. The numbers indicate 3 possible pathways for tectobulbar axons as described in the text. $b$, Retrogradely labeled cell bodies in an area indicated in $a$. c , Higher magnification of an area corresponding to $b$. Note the simple round or oval morphology of the cell bodies. They are located on the ventricular side of the fascicles. The processes grow towards the pial surface first, before joining a fascicle. Arrowheads point at a bending of the processes underneath the pial surface. $d-f$. More complex cells that have already developed highly branched dendritic arborizations. These cells are rarely observed and therefore represent only a minor population in the E6 optic tectum. $g$, Anterograde staining of the ipsilateral and contralateral projecting axons. Note the transition of the fasciculated (arrowheads) to the seemingly unfasciculated (arrows) growth pattern at the point of ramification (star). The broken line indicates the ventral midline. The contralateral projection is coursing nearer to the midline compared to the ipsilateral. A few aberrant axons can be observed outside the main axonal path. Scale bars: $b, 100 \mu \mathrm{m} ; c-f, 40 \mu \mathrm{m} ; g, 200 \mu \mathrm{m}$. 
the ventricular proliferation zone (LaVail and Cowan, 1971b; Puelles and Bendala, 1978). The most superficial layer is invaded by retinal axons starting on $\mathrm{E} 6$ from the anterioventral pole (Rager and von Oeynhausen, 1979). By E8, retinal axons have formed the SO. Thus, in sections of E8 tecta, the immunoreactivity of retinal and tectal axons can be directly compared. The plane of sectioning was chosen in an anterior-to-posterior direction, perpendicular to the tectobulbar axons, to show their fasciculated appearance (best illustrated in Fig. $4, f, l$ ).

G4 and F6 (anti-neurofascin) immunoreactivity in the E5 and E8 optic tectum is confined to layers bearing axons (Fig. 4, $b$, $h, f, l)$. Cell bodies are not stained. Both antibodies label the same layers, but the neurofascin immunofluorescence is considerably weaker compared to $\mathrm{G} 4$ staining. In addition, the neurofascin immunofluorescence is not homogeneously distributed within each fiber bundle in sections of E5 optic tecta. The ventricular part of each fascicle shows a stronger signal compared to the part that faces the meninges [compare the spatial distribution of the immunoreactivity of neurofascin (Fig. 4b) with the immunofluorescence of G4 (Fig. 4f), which labels all axons throughout the fascicle]. In the E8 optic tectum, neurofascin staining of the tectobulbar axons is too weak for a detailed investigation of its spatial distribution. A corresponding nonhomogeneous staining for neurofascin has been described for retinal axons in the optic fiber layer of the embryonic retina (Rathjen et al., 1987b). The G4 antibody, in contrast, uniformly labels tectobulbar fascicles within both the marginal zone at E5 and the SAC at E8 (Fig. 4, f,l). Between E5 and E8, the fascicles increase in size by the addition of new processes. The expansion of each fascicle occurs radially, along the ventricular/pial axis. In contrast, the diameter of each fascicle in the anterior-toposterior direction remains constant, resulting in a comb like structure of the SAC in the G4-stained E8 mesencephalon (Fig. 4l). While F6 and G4 only label axon-bundle-containing laminae, T61 and N-CAM show a more general distribution (Fig. $4, c, i$, and $e, k$ ). Although the axon-containing layers are preferentially stained, both antigens also appear within the neuroepithclium at E5 and the inner cortical plate (IC) at E8.

The monoclonal antibody Julia-1 was used to localize growth cones because it binds to a protein present on growth cones but not on the rest of the axon nor on the cell bodies of retinal and tectobulbar axons (L. Niehörster, S. Kröger, and U. Schwarz, unpublished observations; see also Schwarz et al., 1987). On E5, immunofluorescence of Julia-1 antigen is restricted to the axon-bearing marginal zone of the mesencephalon (Fig. $4 d$ ). The staining is observed only on substructures within each fascicle, which roughly correspond in size and location to the distribution of growth cones also found in electron micrographs of the same tissue (data not shown). At E8, the growth cones of tectobulbar axons within the SAC are preferentially labeled, but punctate staining is also observed within the IC and the SO (Fig. 4j). This result indicates that even at E8, there are still growth cones present in the SAC. Nothing is known about the structures stained within the IC but staining of the SO could be due to the growth cones of invading retinal axons. Within each tectobulbar fascicle on E5 and E8, growth cones are evenly distributed throughout each axon bundle without any preference to the medial or lateral side. This is consistent with electron microscopic investigations showing growth cones randomly distributed in each fascicle (S. Kröger, unpublished observation).

To establish the specificity of the antibodies used for staining, we investigated their binding to proteins that had been separated by SDS-PAGE and transferred to nitrocellulose. In immunoblots of homogenates from E5 (Fig. 5A, 2) and E8 (Fig. 5A, 3) optic tectum, the $\mathrm{F} 6$ antibody recognizes a minor component at $180 \mathrm{kDa}$ and a more prominent doublet at $160 \mathrm{kDa}$. In contrast, affinity-purified neurofascin from adult chick brain forms a major diffuse band at $135 \mathrm{kDa}$ and minor bands at 180 and $160 \mathrm{kDa}$ (Fig. 5A, 1). The different staining patterns of affinity-isolated material and material from embryonic tecta are probably due to the generation of neurofascin-related polypeptides by proteolytic degradation during purification of the affinity-isolated material as has been previously reported by Rathjen et al. (1987b).

Antibodies against $\mathrm{G} 4$ protein detect, in E5 and E8 mesencephalon, a weak band at $200 \mathrm{kDa}$ and a major component at $135 \mathrm{kDa}$ (Fig. 5A, 5, 6). This is identical to the pattern obscrved after separating immunoaffinity-isolated material from adult chick brain (Fig. $5 A, 4$ ).

N-CAM is detected in protein blots of E5 (Fig. $5 B, 1$ ) and E8 (Fig. $5 B, 2$ ) optic tectum as a broad band with an apparent molecular weight between $180-350 \mathrm{kDa}$, which reflects the structural heterogeneity of the protein as previously described (Hoffrran et al., 1982). This diffuse staining corresponds to the embryonic (E)-form of N-CAM, which is highly glycosylated, with as much as $30 \%$ of its mass due to polysialic acid. E10 tectal tissue, which contains this high-molecular-weight E-form of N-CAM, and E10 retina, with the predominantly low-molecular-weight (due to much less glycosylation) adult (A)-form of N-CAM (Schlosshauer et al., 1984) and affinity-purified N-CAM from adult chick brain, which migrates predominantly as bands of 120,140 and $180 \mathrm{kDa}$, were used as controls (Fig. $5 B, 3-5)$.

The T61 monoclonal antibody recognizes a single protein migrating at approximately $480 \mathrm{kDa}$ in the SDS gels of E5 (Fig. $5 B, 6$ ) and $\mathrm{E} 8$ (Fig. $5 B, 7)$ mesencephalon. This pattern is identical to the bands observed with E10 tectum, E10 retina, and adult whole brain (Fig. 5B, 8-10), tissues in which the T61 antigen has already been characterized (R. Babiel, W. Reckhaus, and S. Henke-Fahle, unpublished observations).

Taken together, these results confirm that the antibodies used to characterize tectobulbar axons in cryostat sections bind to the expected proteins in immunoblots. None of the antibodies used discriminates between retinal and tectobulbar axons in immunologically stained sections of E8 optic tectum.

\section{In vitro culture of tectobulbar axons}

To investigate the function of identified molecules during development of the tectobulbar pathway, we turned to cxplant cultures because they cause less disruption and less mechanical stress to the cells. In addition, processes sometimes leave the explanted tissue in a direction that resembles their in vivo orientation (Raymond-Johns et al., 1978; Halfter et al., 1983). Stripes of E5 mesencephalon show vigorous neurite outgrowth when explanted with the former meningeal side facing the underlying basal lamina substrate (Fig. 6). Axons emerging from the explanted tissue grow at a speed of $40 \pm 5 \mu \mathrm{m} / \mathrm{hr}$ (mean \pm $\mathrm{SEM} ; N=5$ ) and reach a length of approximately $1.5 \mathrm{~mm}$ after $40 \mathrm{hr}$, the normal culture period. These axons grow in fascicles, indicating a preference of adhesion to other neurites compared to the underlying substratum. Growth cones are visible at the tip of each fascicle. Branching of axons growing in vitro was never observed, but microspikes were sometimes visible proximal to the growth cone. Axons did not extend more than 3 

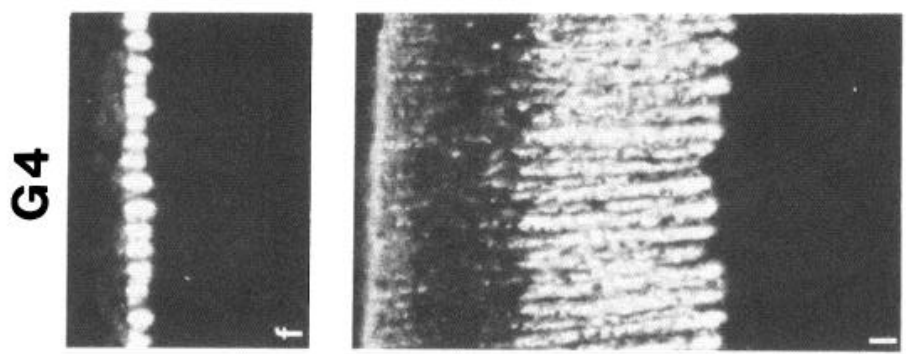

के 졀

临.

范

起

色

녕 응

政
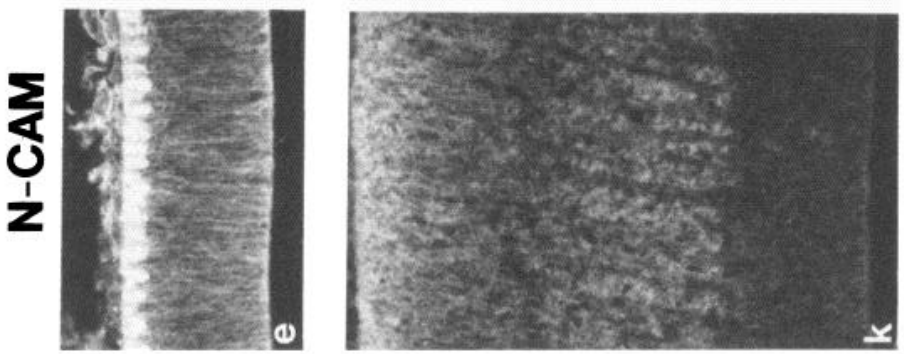

进氙

बै हैं

영

.

들

总惫

要管
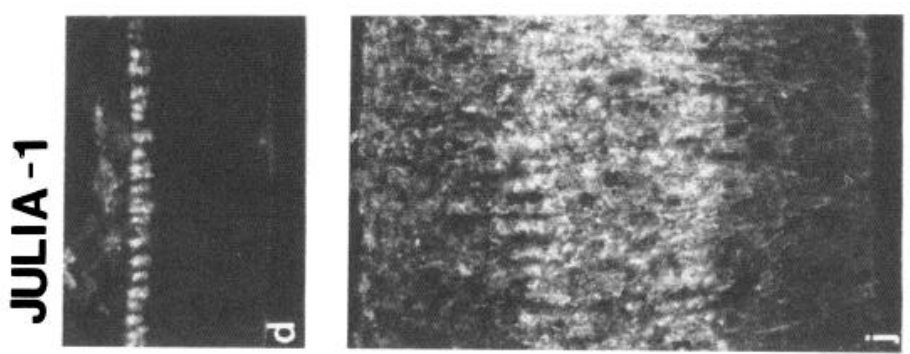

ड़

可.

능

营青

这客

乙望要

की

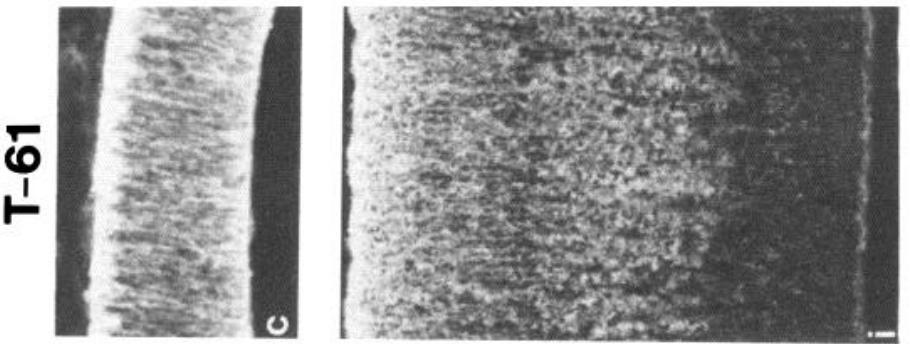

is

骂>

$\approx$

vis

号春

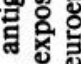

음

동

s.
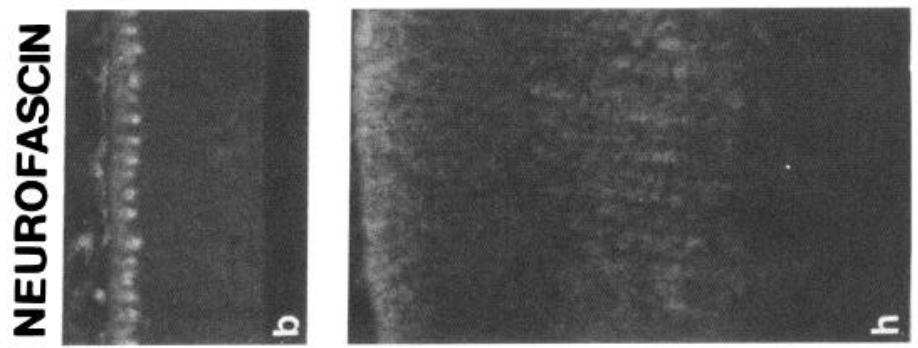

氮

焉

응

분손

o

음

政
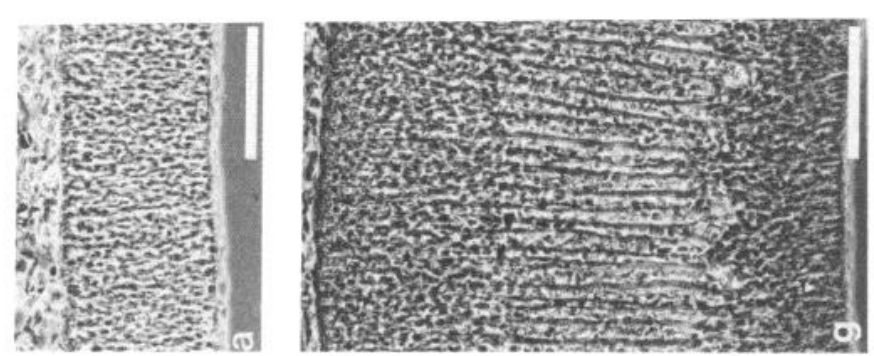

등혈

명응

응

उु

ab

응

写守莒

正

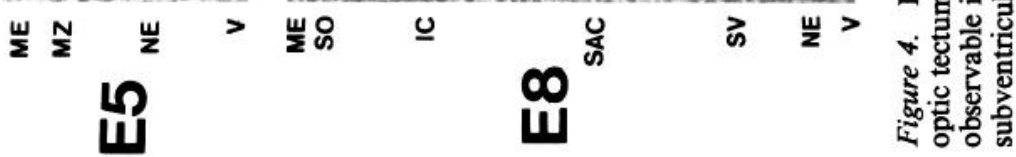




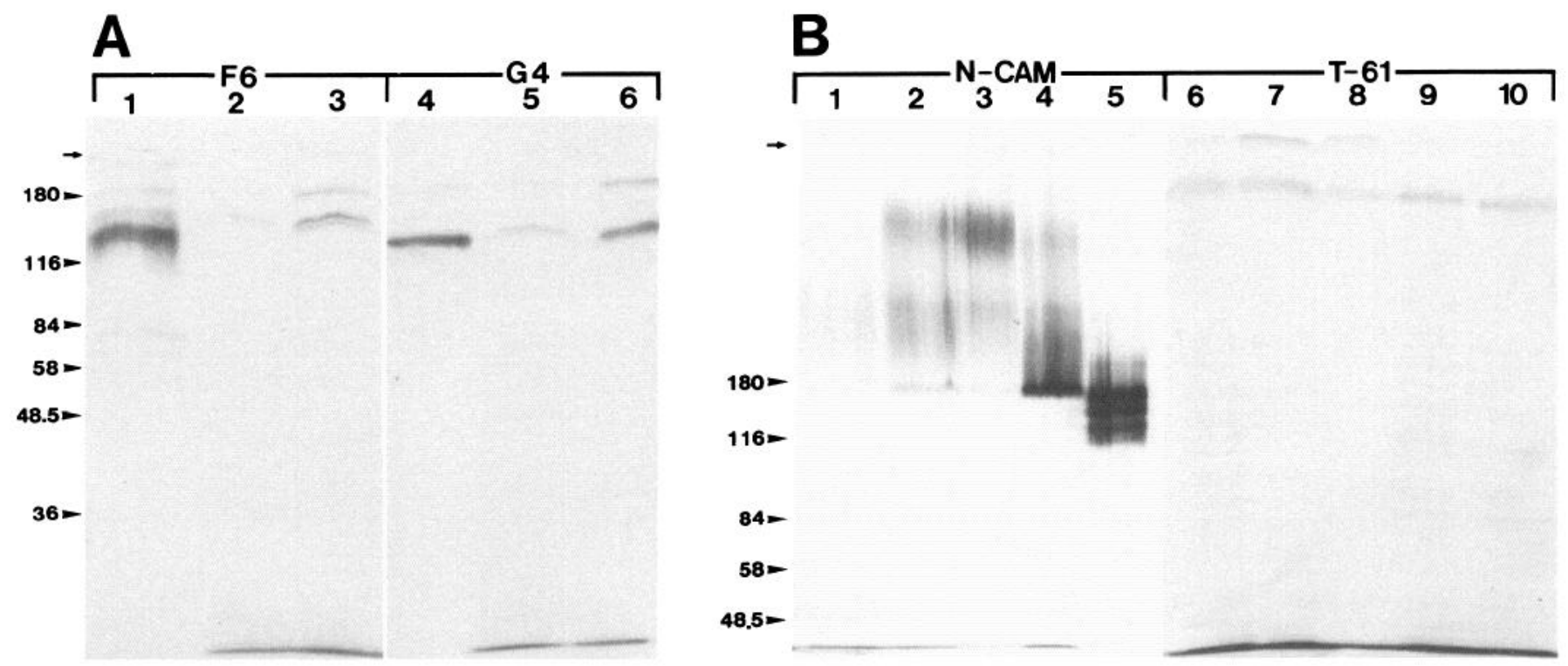

Figure 5. Western blots showing neurofascin, G4, N-CAM, and T61 reactivity after SDS-PAGE in $7.5 \%(A)$ or $5 \%(B)$ gels. $A: 1-3$, Binding of polyclonal anti-neurofascin antibodies (F6) to affinity-purified neurofascin from adult chick brain (lane 1) and homogenates from E5 (lane 2) and E8 (lane 3) optic tectum. 4-6, Binding of anti-G4 polyclonal antibodies to affinity-purified G4 antigen from adult chick brain (lane 4) and homogenates from E5 (lane 5) and E8 (lane 6) optic tectum. B: 1-5, Binding of polyclonal anti-N-CAM antibodies to E5 (lane 1), E8 (lane 2), and E10 (lane 3) optic tectum, as well as E10 retina (lane 4) and affinity-purified N-CAM from adult chick brains (lane 5). 6-10, T61 immunoreactivity in E5 (lane 6), E8 (lane 7), and E10 (lane 8) optic tectum, as well as in E10 retina (lane 9) and whole-brain extract (lane 10). One- $\mu 1$ samples with approximately $0.5 \mu \mathrm{g}$ protein were applied to each lane. The molecular weights of standard proteins are indicated on the left of each gel. The arrows on the left side of $A$ and $B$ indicate the border between the stacking and resolving gel. Binding of antibodies was visualized by the HRP method.

$\mathrm{mm}$ in length because the neurites start to degenerate approximately $80 \mathrm{hr}$ after explantation. The reasons for this cell death are unknown. Neurites leave both sides of the explant stripe in equal amounts, but the first axons appear earlier on the side formerly facing the ventral part of the mesencephalon. Therefore, the axon front on this side is often slightly further advanced than its dorsal counterpart. Non-neuronal cells were never observed leaving the stripe if the mesencephalon was perfectly flatmounted prior to explantation. Occasionally, the cell bodies of the tectal axons were located outside the explant stripe. The addition of Ara $\mathrm{C}$ to the medium had no detectable effect on the number of axons leaving the explanted tissue, indicating that at least most of the cells extending processes were already postmitotic at the time of explantation.

DiI administered to fixed neurites emerging from the tectal explants retrogradely stains cell bodies within the stripe. These cells are round or oval-shaped and located close to the former meningeal surface that, in vitro, faces the substratum (not shown). The position of the retrogradely labeled cells in the explant stripe corresponds to the position of tectobulbar cell bodies labeled with DiI in vivo. In addition to the position of the cell bodies, the antigenicity of the processes was investigated. Neurites leaving the tectal explant were stained with antibodies against the T61 antigen, neurofascin, G4 protein and N-CAM (Fig. 7, $A-$ $D$ ). All 4 antigens are expressed by the axons in vitro, indicating that the outgrowing processes might be tectobulbar axons.

Tectobulbar axons in vivo and the axons leaving the explant stripe in vitro express N-CAM, G4 protein, neurofascin, and T61 antigen. All of these proteins have previously been shown to affect the pattern of neurite outgrowth. To test the possible function of these proteins on the growth of tectal axons in vitro, we investigated the influence of antibodies against these proteins in the explant culture system. The fasciculated growth of the axons in vitro is easily observable and therefore facilitates the analysis of molecules involved in neurite-neurite interactions. Addition of anti-G4 F(ab) ${ }_{2}$ fragments to the culture medium results in a clear defasciculation without interfering with the rate of axonal elongation (Fig. 8, $a, b$ ). This defasciculation is therefore probably due to a reduction of side-to-side interactions among tectobulbar axons while neurite-substratum interactions remain unaffected. Ten sets of experiments with 4 explants each were carried out to quantify these results. Axonal fasciculation was disturbed in all experiments if the final concentration of anti-G4 $\mathrm{F}(\mathrm{ab})_{2}$ fragments in the medium was $0.5 \mathrm{mg} / \mathrm{ml}$ and more. If the concentration was reduced to less than $0.1 \mathrm{mg} / \mathrm{ml}$, no effect on the bundling of axonal processes was observed. Addition of excess affinity-purified G4 protein together with the $\mathrm{F}(\mathrm{ab})_{2}$ fragments abolished the effect of the anti-G4 antibodies. $\mathrm{F}(\mathrm{ab})_{2}$ fragments of anti-N-CAM and anti-neurofascin antibodies at the same or at even higher $(1 \mathrm{mg} / \mathrm{ml})$ concentration had no detectable influence on the growth pattern of the axons in vitro (data not shown; 8 independent experiments with 4 explants each). The rate of axonal elongation in the presence and in the absence of anti-G4, anti-N-CAM, and anti-neurofascin antibodies was $40 \pm 5 \mu \mathrm{m} / \mathrm{hr}(N=5)$.

The outgrowth of tectal fibers from explant stripes is substantially reduced in number and length when the T61 monoclonal antibody is included in the culture medium (Fig. 9, $a, b$ ). In the presence of the T61 antibody, the length of the axon front after $40 \mathrm{hr}$ in culture was reduced to $27 \pm 1.4 \%(N=16)$ of that from control stripes incubated with a control antibody. To compare the number of axons growing in vitro in the presence and in the absence of the T61 antibody, we also counted the number of identifiable fascicles leaving segments of $1000 \mu \mathrm{m}$ of the explant stripes. The T61 antibody reduced the number of fascicles to $50 \pm 3.2 \%(N=16)$ of controls. The total number 


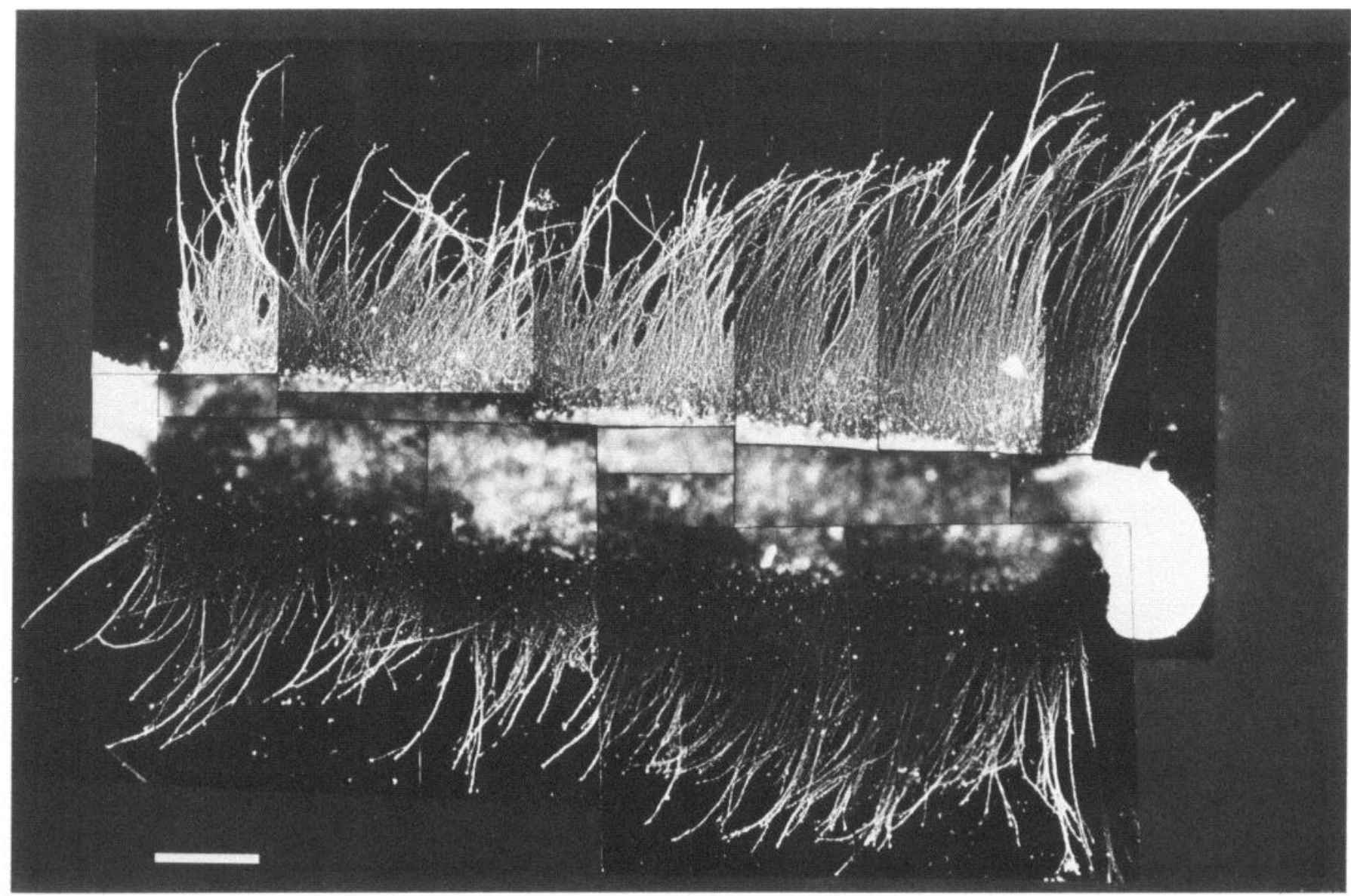

Figure 6. Explant stripe from E5 chick optic tectum cultured $40 \mathrm{hr}$ on E8 retinal basal lamina. Vigorous outgrowth of processes along the whole length of the stripe can be seen. Axonal outgrowth is confined to the basal lamina and not observed on the surrounding polylysine coating. The mesencephalon has been spread on a nitrocellulose filter and cut into stripes in an anterior-to-posterior direction. The stripes were placed with the former meningeal side facing the substrate. Axons were counterstained with the antibody Q211. The nitrocellulose filter was removed during processing. Note that outgrowth of axons is observed on both sides of the explant stripe, but the axon front at the side that was originally facing in a ventral direction in the embryo (and is directing up in the actual figure) is slightly further advanced. Scale bar, $400 \mu \mathrm{m}$.

of fascicles per $1000-\mu \mathrm{m}$ segment was reduced from an average of 19.9 in the absence to 10.1 in the presence of the antibody. In addition, the size of the fascicles seemed to be smaller in the presence of the T61 antibody, but no attempts were made to quantify this difference. Addition of the antibody to alreadygrowing axons resulted in a cessation of elongation within $2 \mathrm{hr}$, but growth cones remained visible. Inhibition of growth is reversible by exchanging the medium and, therefore, not due to general cytotoxity. In 7 of 8 experiments with 2 explant stripes each, the axonal front started to advance again $3 \mathrm{hr}$ after removal of the T61 antibody. The cultures had previously been exposed to the antibody for $5 \mathrm{hr}$. In 1 experiment, the axons did not recover; instead, they started to form varicosities typical for degenerating axons. In this case, the growth cones had collapsed. Outgrowth of axons from dorsal root ganglia explanted on retinal basal laminae were not influenced by the same concentration of the T61 antibody (not shown; see Henke-Fahle and Bonhoeffer, 1983).

\section{Discussion}

Wholemount preparations of the embryonic CNS have been especially advantageous compared to serial sectioning in the investigation of specific neuronal subtypes and of long-distance axonal projections (Goldberg, 1974; Halfter and Deiss, 1984; Aitken, 1987). This technique, in combination with specific antibodies, provides an excellent view of the developing neuronal architecture, including complete axonal pathways, because it combines the sensitivity of fluorescent labels with the selectivity of antibody binding.

Our results using immunologically stained, flat-mounted optic tecta show tectobulbar axons that have already extended a considerable distance by E3. The origin of the processes is predominantly the dorsal third of the mesencephalon. This is in agreement with previous investigations that have shown that tectal cells become postmitotic around E2 in the dorsal-most part of the mesencephalon and that tectobulbar axons are the first processes to appear in the optic tectum (Windle and Austin, 1935; Lyser, 1966; LaVail and Cowan, 1971a, b; Puelles and Bendala, 1978; Layer et al., 1988).

While the first tectobulbar axons display a strictly ipsilateral course, some of the later-appearing axons continue to grow straight and cross the ventral midline before turning in a caudal direction. The origin of these commissural axons cannot be localized to a specific area of the optic tectum because placing DiI crystals at various positions on the tectal surface always 

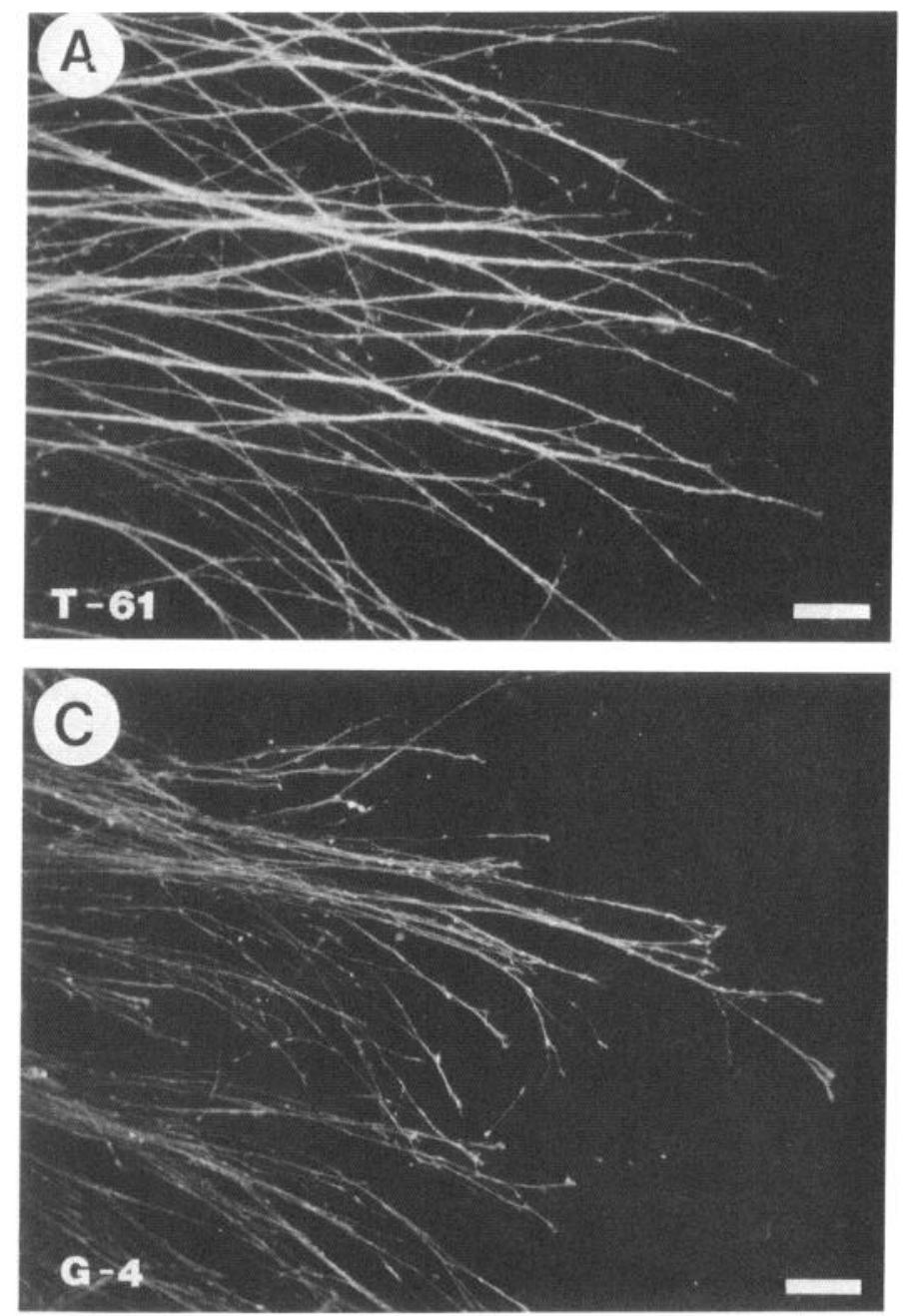
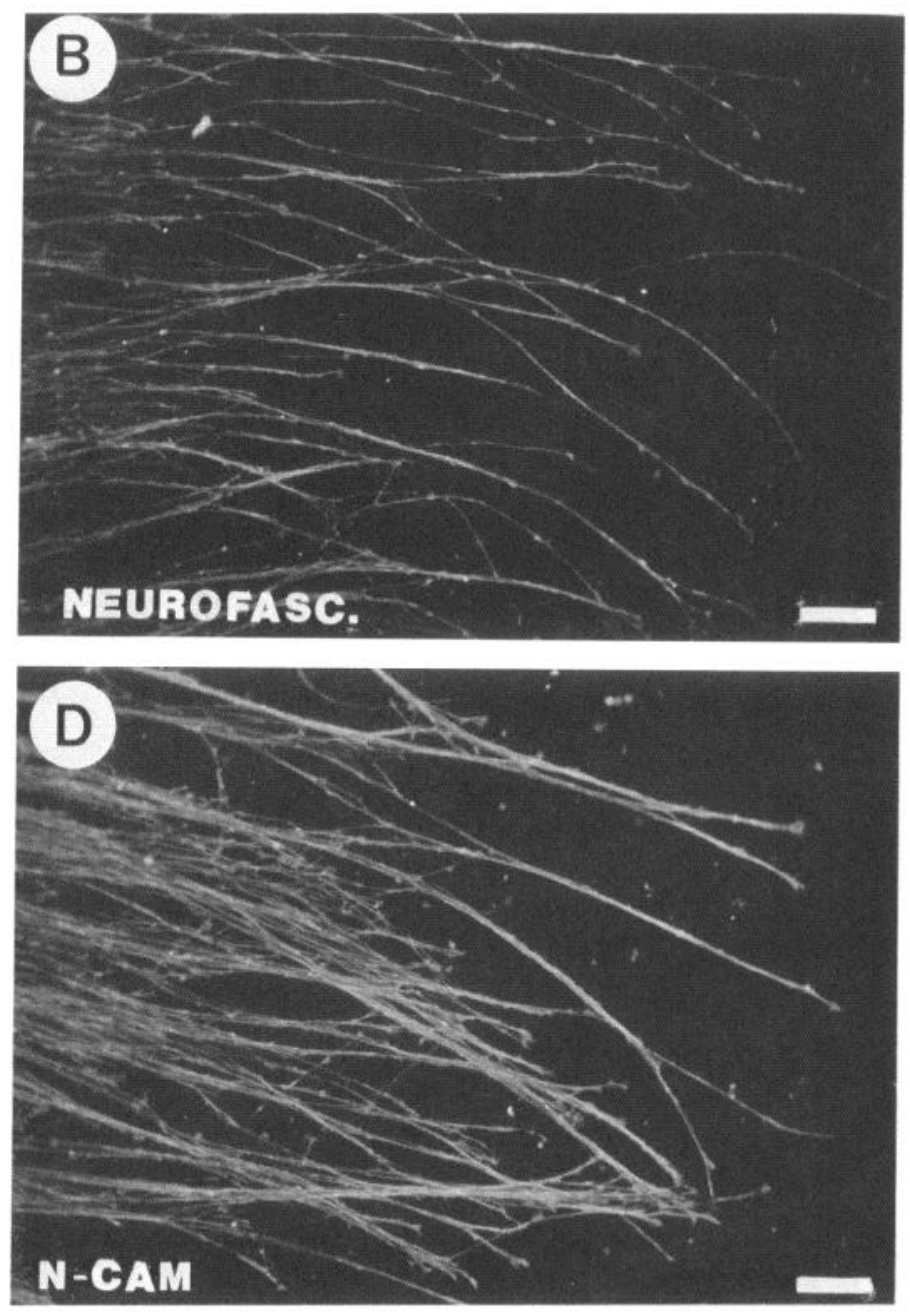

Figure 7. Expression of T61 antigen $(A)$, neurofascin $(B), \mathrm{G} 4$ protein $(C)$, and N-CAM $(D)$ by tectal axons in vitro. Stripes of the optic tectum were explanted on a basal lamina substrate and cultured for $40 \mathrm{hr}$. Explants were then fixed in $4 \%$ paraformaldehyde and stained. Areas with a relatively low axon density were selected for documentation. The explant stripes are located on the left side, outside the picture. Scale bars, $75 \mu \mathrm{m}$.

labels the same amount of ipsi- and contralateral tectobulbar axons. In seems more likely that a random distribution between ipsi- and contralateral axons exists at this early stage.

Our investigations are in agreement with previous work of Domesick and Morest (1977), in which they reported that, beginning on E5.5, the cell bodies of tectobulbar axons change their location from a more ventricular position underneath the fascicle-containing layer to a more meningeal position on top of the fascicles before extending dendritic processes. They have described several distinct and strictly time-locked cell stages in this translocation process: radial, tangential, oblique, and young ganglion cell stages. Our results support their findings because, in DiI-labeled wholemounts, the few tectobulbar cell bodies that had already extended highly branched dendritic processes were always located between the fascicles and the pia, while the "simple" round and oval-shaped cell bodies were located underneath the fascicles. Moreover, the complex cells were preferentially located in the anterior part of the optic tectum, corresponding to the advanced developmental stage of this area as described by Domesick and Morest (1977).

The strong bundling within the optic tectum is the most characteristic feature of tectobulbar axons and clearly distinguishes them from the unfasciculated retinal axons. The formation of thick fascicles probably helps the ordered displacement of the bundles from the most superficial layer of the optic tectum deeper into the tissue, because cells that migrate out of the ventricular proliferating zone through the fascicles to form the cortical plate cannot easily divert axons out of the fascicles if the single fibers tightly adhere to each other. In addition, the ordered perikaryal translocation process as described by Domesick and Morest (1977) might be facilitated by the axons being tightly fixed within the fascicles. Taken together, we assume that the fasciculated growth pattern of tectobulbar axons is a necessary prerequisite for their normal development.

Stripes of optic tectum explanted on a suitable substrate show vigorous extension of neurites. Several lines of evidence suggest that these processes are tectobulbar axons: Outgrowing axons can be obtained from mesencephalic explants at ages between E3-E6, corresponding to the time when tectobulbar axons occupy the most superficial layer of the optic tectum. Explantation of later stages where the tectobulbar fascicles have been displaced deeper into the tissue results in a decreased amount of axonal outgrowth, presumably because direct contact of the axons to the substrate at the time of explantation is a necessary prerequisite for process extension. In addition, the processes in vitro express N-CAM, neurofascin, T61, and G4, as do tecto- 

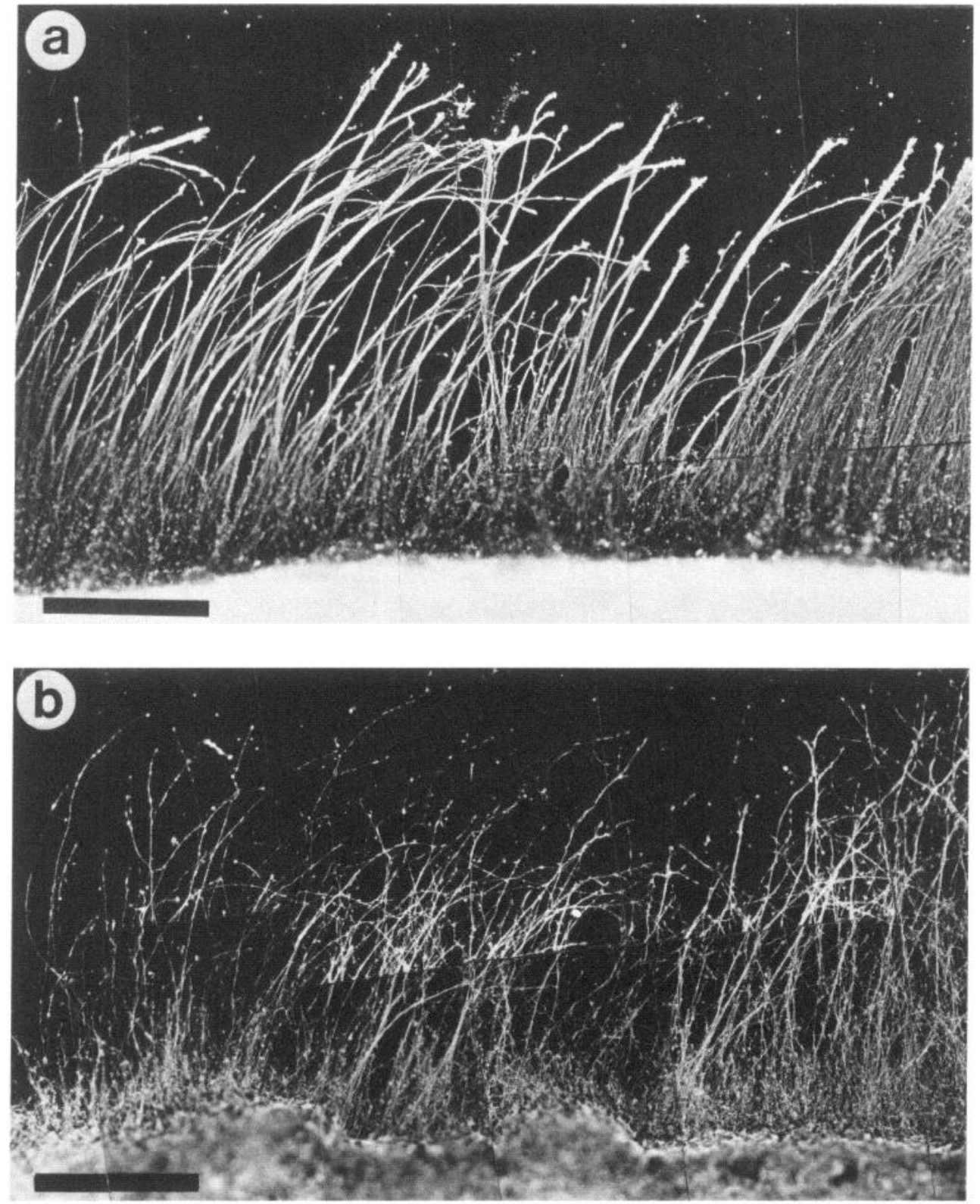

Figure 8. Defasciculation of tectobulbar axons by anti-G4 antibodies. Parallel stripes of $\mathrm{E} 5$ optic tectum were cultured for $40 \mathrm{hr}$ on the retinal basal lamina either in the presence of rabbit serum as a control $(a)$ or in the presence of anti-G4 $\mathrm{F}(\mathrm{ab})_{2}$ fragments $(b)$. The final concentration of the antibodies in the medium was $0.5 \mathrm{mg} / \mathrm{ml}$. Note that the length of the axons is not influenced by anti-G4 antibodies, but the fasciculation is completely lost. Axons were visualized by staining with the Q211 antibody. Scale bars, $40 \mu \mathrm{m}$. bulbar axons in vivo. In fact, tectobulbar axons are the only axons in the central part of the E5 optic tectum expressing the G4 antigen as shown by the immunofluorescent staining of wholemounts with the anti-G4 antibodies. Moreover, retrogradely labeled cell bodies in the explant stripe occupy the same position as the tectobulbar cell bodies in vivo. Although these results suggest that the axons leaving the explant stripe are tectobulbar processes, we cannot completely rule out the possibility that they represent an inhomogeneous population of several types of neurites.

The lack of obvious effects of the mitosis inhibitor Ara C, when included in the culture medium, indicates that the transition from the mitotically active neuroepithelial cell precursor to the postmitotic axon-bearing neuron is at least not prominent in culture. We cannot decide at present whether the axonal growth observed in vitro is restricted to cells that were postmitotic at the time of preparation with axons sufficiently short to avoid being cut during stripe preparation and therefore rep- resent de novo growth, or whether the outgrowing axons represent regenerating processes.

The basal lamina preparation used for this study has been shown to be an excellent substrate for neurons from the central and peripheral nervous system (Halfter et al., 1987). It was mechanically isolated from E8 avian embryonic retina (Halfter et al., 1987). This transparent preparation is initially covered by a carpet of neuroepithelial cell endfeet that can be removed by detergent treatment. Tectobulbar axons grow on both the denuded and the endfeet-containing preparation with the same pattern and the same speed. This indicates that the outgrowthpromoting activity for tectobulbar axons is not exclusively endfeet associated, but it is also present in the lamina sheet itself. We do not know, however, which molecule(s) of the multicomponent basal lamina is the outgrowth-promoting substrate used by tectobulbar axons in vitro. Likewise, we have no information concerning the substrate on which the axons grow in vivo. The extreme fasciculation, as well as the presence of growth cones 


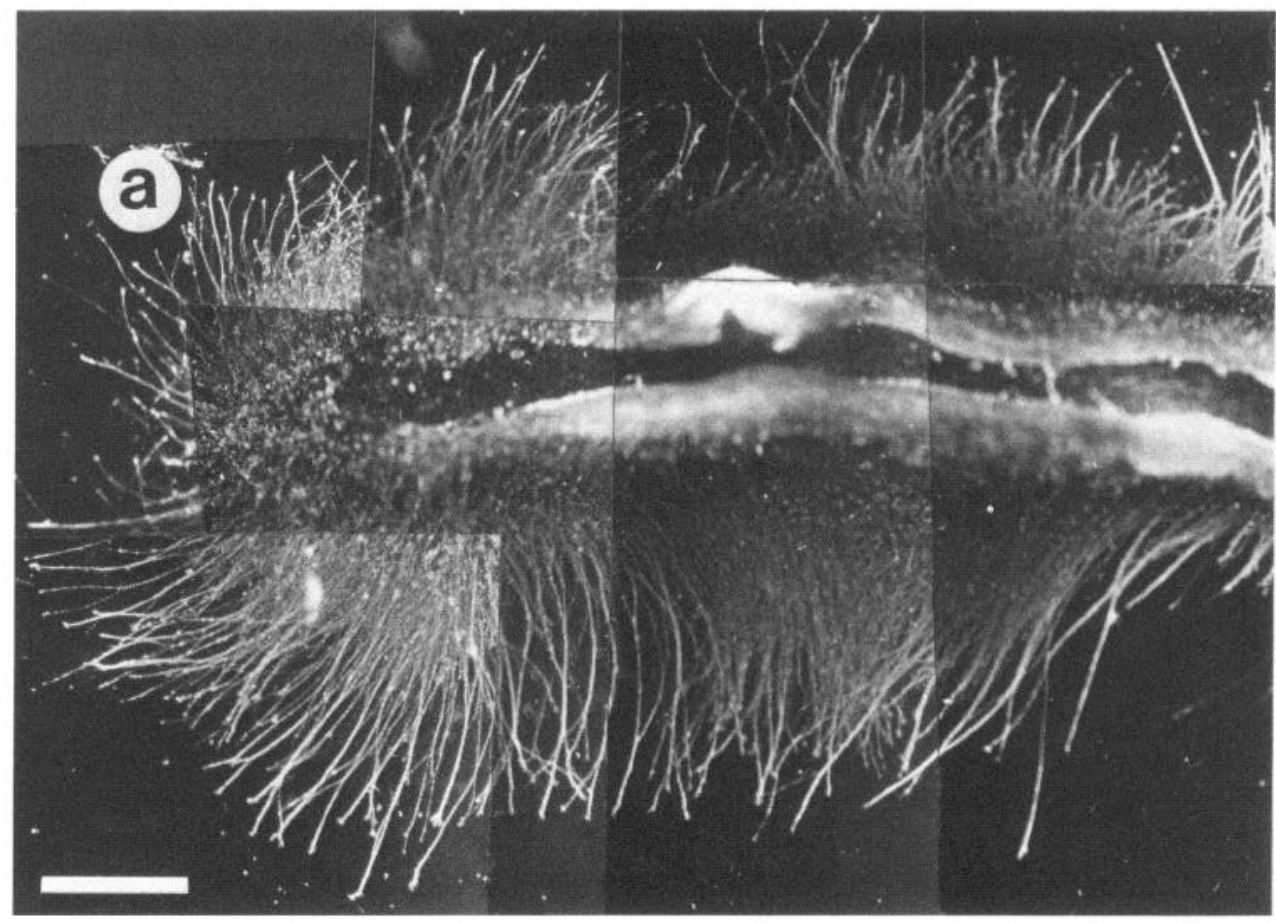

Figure 9. Inhibition of tectobulbar axon outgrowth by the T61 monoclonal antibody. Stripes of E5 optic tectum that were previously located next to each other were cultured for $40 \mathrm{hr}$ in the presence of a control antibody (Q211; a) or in the presence of approximately $80 \mu \mathrm{g} / \mathrm{ml}$ final concentration of the T61 antibody $(b)$. The amount and length of processes leaving the explant stripe are reduced in the presence of the T61 antibody in the culture medium. The neurites were visualized by indirect immunofluorescence using the Q211 antibody. Scale bars, $500 \mu \mathrm{m}$.

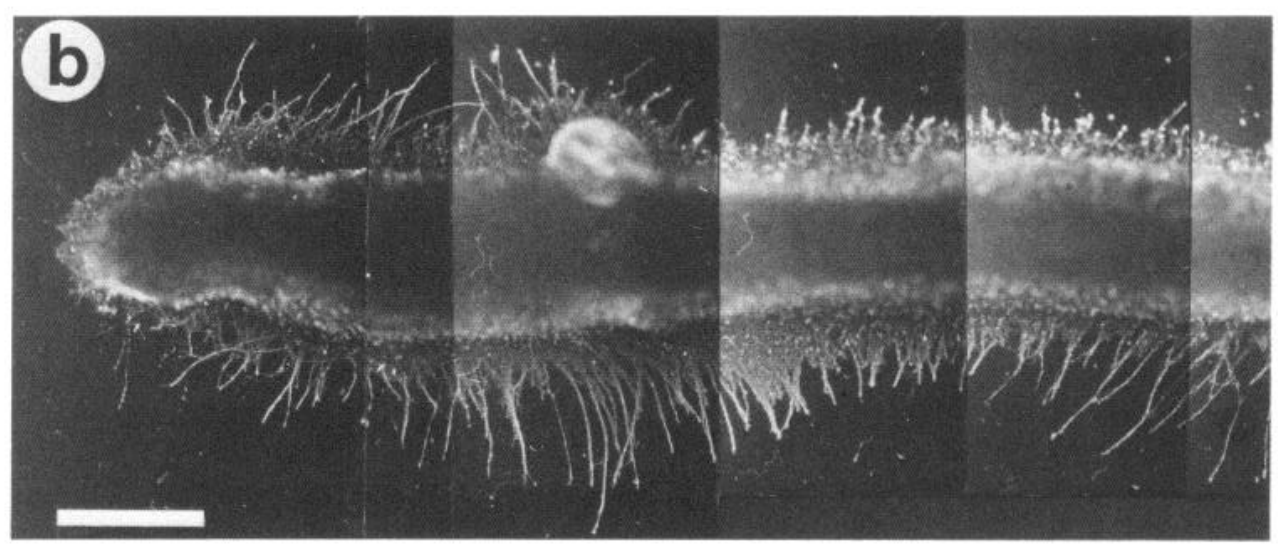

inside the fascicles in vivo, suggest that the tectobulbar axons grow on molecules preferentially expressed on the surface of axons and not on the neuroepithelial cells, which is the other cellular component within their immediate environment.

Fasciculated growth of tectobulbar axons is likely to be the result of the expression of molecules involved in neurite-neurite interaction. In the course of this investigation, several molecules with this biological function could be identified on the surface of tectobulbar axons and in Western blots of tectal tissue. These include neurofascin (Rathjen et al., 1987b), N-CAM (Hoffmann et al., 1982), and G4 antigen (Rathjen et al., 1987a), all of which are involved in $\mathrm{Ca}^{2+}$-independent neural cell adhesion. The spatiotemporal distribution of G4 and N-CAM immunoreactivity in the mesencephalon matches and extends results obtained in previous investigations (Daniloff et al., 1986; Lemmon and McLoon, 1986). The establishment of an in vitro culture system for tectal axons that resembles the characteristic fasciculated growth observed in vivo made it possible to investigate the functional role of these proteins. Antibody perturbation studies show that blocking G4-antigen activity causes defasciculation of the axons in vitro. We consider the effect of G4 antibodies on fasciculation specific because $\mathrm{F}(\mathrm{ab})_{2}$ fragments of polyclonal antibodies against neurofascin and N-CAM, which also bind to the cell surface of tectobulbar axons in vivo and in vitro, do not exhibit a comparable effect even at higher concentrations. This result indicates that fasciculation of tectobulbar axons is mediated to a large extent by $\mathrm{G} 4$, at least in vitro. We cannot exclude the possibility that neurofascin and N-CAM have a function in axon-bundle formation in vivo because the defasciculation was investigated on a retinal basal lamina preparation that does not represent the in vivo environment of tectobulbar axons. Alternatively, interneuronal N-CAM interactions may not predominate. For instance, N-CAM-mediated homophilic binding could be primarily involved in the adhesive events between the tectobulbar axons and the surrounding neuroepithelial cells, because both cell types express N-CAM. N-CAM has previously been shown to mediate the interaction between neurons and non-neuronal cells (Keilhauer et al., 1985). Perturbation studies 
with injections of the different antibodies into the mesencephalic ventricle in ovo are currently being undertaken to clarify the role of these proteins in vivo.

The monoclonal antibody 161 reversibly reduces the growth of tectobulbar axons in culture. This antibody has been shown to inhibit growth of retinal axons in vitro on various substrates (Henke-Fahle and Bonhoeffer, 1983) and in organ-cultured avian embryonic eyes (Halfter and Deiss, 1986), suggesting a prominent function for the antigen in axonal extension. The antibody binds to a glycoprotein that is present in the central, but not in the peripheral, nervous system (Babiel et al., unpublished observations) and does not influence axonal growth from PNS explants (Henke-Fahle and Bonhoeffer, 1983). The antigen has been localized by electron microscopy to retinal axons and their extracellular matrix environment in vivo (Halfter and Fua, 1987) and in vitro (Babiel et al., unpublished observations), indicating a possible synthesis and secretion of the protein by the axons. Distribution of the antigen in the mesencephalon and synthesis of the protein in vitro by tectobulbar axons is in agreement with these assumptions.

The fasciculated growth in the dorsal-to-ventral direction within the tectum is in contrast to the seemingly unfasciculated growth in the caudal direction parallel to the ventral midline. The transition from a fasciculated to an unfasciculated growth pattern occurs at the point where the contralateral projection splits off and the ipsilateral projection changes direction to the posterior. Every axon, therefore, has a proximal fasciculated and a distal unfasciculated segment. It is conceivable that the loss of fasciculation is due to the spatially restricted expression of molecules that mediate bundling of axons. It has been shown for commissural axons in the rat spinal cord that 2 different cell-surface glycoproteins are segregated on different segments of the same axons, probably because synthesis of 1 protein is terminated and the other is switched on after the growth cone has reached a critical point in its axonal trajectory (Dodd et al., 1988). One of these proteins is L1, the mouse homologue to chicken G4 protein (Rathjen et al., 1987a). Differential expression of this protein only on parts of a commissural axon results in localized fasciculation within the rat spinal cord. Experiments designed to determine whether a similar localized expression of a protein-mediating fasciculation occurs along the tectobulbar pathway are in progress. Unfortunately, the immunoreactivity of tectobulbar axons is difficult to investigate at the point of ramification because, in this area, they are covered by a dense network of other fibers that are themselves immunologically positive for $\mathrm{G} 4$.

The orientations of axons in vivo and in the stripe cultures differ considerably. While axons in the optic tectum are strictly polarized in the ventral direction at a very early stage, this orientation is not observed in vitro, though the axon front that, in the optic tectum, pointed in ventral direction is, in vitro, always further advanced than the front directed towards the former dorsal side. Oriented outgrowth from explanted tissue has previously been obscrved in goldfish (Raymond-Johns et al., 1978) and chick (Halfter et al., 1983) retinal axons. In the case of the chick retina, directionality of outgrowth could be destroyed by treatment of the explant stripe with trypsin or collagenase prior to explantation (Halfter et al., 1983). This procedure removes the inner limiting membrane and the neuroepithelial cell endfeet, thus disturbing the direct environment of retinal axons. In our preparation of the oplic tectum, the meninges, along with the basement membrane (external limiting membrane) and the neuroepithelial cell endfeet, are removed before explantation (S. Kröger and L. Niehoerster, unpublished observations). Therefore, the lack of orientation of tectobulbar axons in vitro could be due to the distortion of the local microenvironment during preparation.

The availability of only a few defined explant culture systems for cells from the CNS that extend axons has been limiting for the in vitro investigation of determinants involved in the generation of the accurate connectivity pattern during embryonic development. The tectobulbar tract represents a new, interesting model system for the functional characterization of molecules involved in the extension, fasciculation, and pathfinding of CNS axons. In addition, wholemounts have shown that the embryonic mesencephalon contains 2 closely apposed layers of orthogonally oriented fibers (i.e., retinal and tectobulbar), which are both now accessible in vitro. This makes it possible to compare both types of axonal processes and to investigate the mechanisms that separate both long-distance projecting fiber pathways, a process that results in the formation of 2 distinct plexiform laminae (SO and SAC, respectively).

\section{References}

Aitken AR (1987) The preparation and use of embryonic brain wholemounts. J Neurosci Meth 19:297-304.

Alvarado-Mallart RM, Sotelo C (1984) Homotopic and heterotopic transplantations of quail tectal primordia in chick embryos: organization of the retinotectal projections in the chimeric embryos. Dev Biol 103:378-398.

Bray D, Hollenbeck PJ (1988) Growth cone motility and guidance. Ann Rev Cell Biol 4:43-61.

Chang S, Rathjen FG, Raper JA (1987) Extension of neurites on axons is impaired by antibodies against specific neural cell surface glycoproteins. J Cell Biol 104:355-362.

Daniloff JK, Chuong C-M, Levi G, Edelmann GM (1986) Differential distribution of cell adhesion molecules during histogenesis of the chick nervous system. J Neurosci 6:739-758.

DeLong GR, Coulombre AJ (1965) Development of the retinotectal topographic projection in the chick embryo. Exp Neurol 13:351-363.

Dodd J, Morton SB, Karagogeos D, Yamamoto M, Jessell TM (1988) Spatial regulation of axonal glycoprotein expression on subsets of embryonic spinal neurons. Neuron 1:105-116.

Domesick VB, Morest DK (1977) Migration and differentiation of ganglion cells in the optic tectum of the chick embryo. Neuroscience 2:459-475.

Fischer G, Künemund V, Schachner M (1986) Neurite outgrowth patterns in cerebellar microexplant cultures are affected by antibodies to the cell surface glycoprotein L1. J Neurosci 6:605-612.

Godement P, Vanselow J, Thanos S, Bonhoeffer F (1987) A study in developing visual systems with a new method of staining neurones and their processes in fixed tissue. Development 101:697-713.

Goldberg S (1974) Studies on the mechanics of development of the visual pathways in the chick embryo. Dev Biol 36:24-43.

Gray GE, Glover JC, Majors J, Sanes JR (1988) Radial arrangement of clonally related cells in the chicken optic tectum: lineage analysis with a recombinant retrovirus. Proc Natl Acad Sci USA 85:73567360 .

Grumet M, Edelmann GE (1984) Heterotypic binding between neuronal membrane vesicles and glial cells is mediated by a specific cell adhesion molecule. J Cell Biol 98:1746-1756.

Halfter W (1987) Anterngrade tracing of retinal axons in the avian embryo with low molecular weight derivatives of biotin. Dev Biol 119:322-335.

Halfter W, Deiss S (1984) Axon growth in embryonic chick and quail retinal whole mounts in vitro. Dev Biol 102:344-355.

Halfter W, Deiss S (1986) Axonal pathfinding in organ-cultured embryonic avian retinae. Dev Biol 114:296-310.

Halfter W, Fua CS (1987) Immunohistochemical localization of laminin, neural cell adhesion molecule, collagen type IV and T61 antigen in the embryonic retina of Japanese quail by in vivo injection of antibodies. Cell Tissue Res 249:487-496. 
Halfter W, Newgreen DF, Sauter J, Schwarz U (1983) Oriented axon outgrowth from avian embryonic retinae in culture. Dev Biol 95:5664.

Halfter W, Reckhaus W, Kröger S (1987) Nondirected axonal growth on basal lamina from avian embryonic neural retina. J Neurosci 7: $3712-3722$.

Henke-Fahle $S$, Bonhoeffer F (1983) Inhibition of axonal growth by a monoclonal antibody. Nature 303:65-67.

Hoffman S, Sorkin BC, White PC, Brackenbury R, Mailhammer R, Rutishauser U, Cunningham BA, Edelman GE (1982) Chemical characterization of a neural cell adhesion molecule purified from embryonic brain membranes. J Biol Chem 257:7720-7729.

Jessell TM (1988) Adhesion molecules and the hierarchy of neural development. Neuron 1:3-13.

Keilhauer G, Faissner A, Schachner M (1985) Differential inhibition of neurone-neurone, neurone-astrocyte and astrocyte-astrocyte adhesion by L1, L2 and N-CAM antibodies. Nature 316:728-730.

Kruse J, Keilhauer G, Faissner A, Timpl R, Schachner M (1985) The $\mathrm{J} 1$ glycoprotein-a novel nervous system cell adhesion molecule of the L2/HNK-1 family. Nature 316:146-148.

I agenaur C, I emmon V (1987) An L1-like molecule, the 8D9 antigen, is a potent substrate for neurite extension. Proc Natl Acad Sci USA 84:7753-7757.

LaVail JH, Cowan WM (1971a) The development of the chick optic tectum. I. Normal morphology and cytoarchitectonic development. Brain Res 28:391-419.

LaVail JH, Cowan WM (1971b) The development of the chick optic tectum. II. Autoradiographic studies. Brain Res 28:421-441.

Layer PG, Rommel S, Bülthoff H, Hengstenberg R (1988) Independent spatial waves of biochemical differentiation along the surface of chicken brain as revealed by the sequential expression of acetylcholinesterase. Cell Tissue Res 251:587-595.

Lemmon V, McLoon SC (1986) The appearance of an L1-like molecule in the chick primary visual pathway. J Neurosci 6:2987-2994.

Letourneau PC, Madsen AM, Palm SL, Furcht I.T (1988) Immunoreactivity for laminin in the developing ventral longitudinal pathway of the brain. Dev Biol 125:135-144.

Lyser KM (1966) The development of the chick embryo diencephalon and mesencephalon during the initial phases of neuroblast differentiation. J Embryol Exp Morphol 16:497-517.

Neukirchen RO, Schlosshauer B, Baars S, Jäckle H, Schwarz U (1982) Two-dimensional protein analysis at high resolution on a microscale. J Biol Chem 257:15229-15234.

Puelles L, Bendala MC (1978) Differentiation of neuroblasts in the chick optic tectum up to eight days of incubation: a Golgi study. Neuroscience 3:307-325.

Puelles L, Amat JA, Martinez-de-la-Torre M (1987) Segment-related, mosaic neurogenetic pattern in the forebrain and mesencephalon of early chick embryos. I. Topography of AChE-positive neuroblasts up to stage HH18. J Comp Neurol 266:247-268.

Rager G (1980) Development of the retinotectal projection in the chicken. Adv Anat Embryol Cell Biol 63:1-92.

Rager G, von Oeynhausen B (1979) Ingrowth and ramification of retinal fibers in the developing optic tectum of the chick embryo. Exp Brain Res 35:213-227.

Rathjen FG, Schachner M (1984) Immunocytological and biochemical characterization of a new neuronal cell surface component (L1 antigen) which is involved in cell adhesion. EMBO J 3:1-10.
Rathjen FG, Wolff JM, Frank R, Bonhoeffer F, Rutishauser U (1987a) Membrane glycoproteins involved in neurite fasciculation. J Cell Biol 104:343-353.

Rathjen FG, Wolff JM, Chang S, Bonhoeffer F, Raper JA (1987b) Neurofascin: a novel chick cell-surface glycoprotein involved in neurite-neurite interactions. Cell 51:841-849.

Raymond-Johns P, Yoon MG, Agranoff BW (1978) Directed outgrowth of optic fibers regenerating in vitro. Nature 271:360-362.

Rhines R, Windle WF (1941) The early development of the fasciculus longitudinalis medialis and associated secondary neurons in the rat, cat and man. J Comp Neurol 75:165-189.

Rogers LA, Cowan WM (1973) The development of the mesencephalic nucleus of the trigeminal nerve in the chick. J Comp Neurol 147: 291-320.

Rösner H, Greis C, Henke-Fahle S (1988) Developmental expression in embryonic rat and chicken brain of a polysialoganglioside-antigen reacting with the monoclonal antibody Q211. Dev Brain Res 42:161171.

Sauer FC (1935) Mitosis in the neural tube. J Comp Neurol 62:377406.

Schlosshauer B, Schwarz U, Rutishauser U (1984) Topological distribution of different forms of neural cell adhesion molecule in the developing chick visual system. Nature 310:141-143.

Schwarz U, von Boxberg Y, Kröger S, Niehörster L (1987) Surface components on axons and their growth cones. In: Molecular biological aspects of neurobiology, Heidelberg: EMBO-EMBL Symposium, $p$ 67.

Senut MC, Alvarado-Mallart R-M (1987) Cytodifferentiation of quail tectal primordium transplanted homotopically into the chick embryo. Dev Brain Res 32:187-205.

Stallcup WB, Beasley L (1985) Involvement of the nerve growth factorinducible large external glycoprotein (NILE) in neurite fasciculation in primary cultures of rat brain. Proc Natl Acad Sci USA 83:12761280.

Thanos S, Bonhoeffer F (1983) Investigations on the development and topographic order of retinotectal axons: anterograde and retrograde staining of axons and perikarya with rhodamine in vivo. J Comp Neurol 219:420-430.

Thanos S, Dütting D (1987) Outgrowth and directional specificity of fibers from embryonic retinal transplants in the chick optic tectum. Dev Brain Res 32:161-179.

Tomaselli KJ, Neugebauer KN, Bixby JL, Lilien J, Reichardt LF (1988) $\mathrm{N}$-cadherins and integrins: two receptor systems that mediate neurite outgrowth on astrocyte surfaces. Neuron 1:33-43.

von Boxberg Y (1988) Protein analysis on two-dimensional polyacrylamide gels in the femtogram range: use of a new sulfur-labeling reagent. Anal Biochem 169:372-375.

Walter J, Kern-Veits B, Huf J, Stolze B, Bonhoeffer F (1987a) Recognition of position-specific properties of tectal cell membranes by retinal axons in vitro. Development 101:685-696.

Walter J, Henke-Fahle S, Bonhoeffer F (1987b) Avoidance of posterior tectal membranes by temporal retinal axons. Development 101:909913.

Windle WF, Austin MF (1935) Neurofibrillar development in the central nervous system of chick embryos up to 5 days' incubation. J Comp Neurol 63:431-463. 